\title{
The Impact of Trade Preferences on Multilateral Tariff Cuts: Evidence for Japan
}

\author{
Tobias Ketterer \\ Directorate General Economic and Financial Affairs, European \\ Commission \\ Daniel M. Bernhofen* \\ American University, CESifo and GEP \\ Chris Milner \\ University of Nottingham, CESifo and GEP
}

February 17, 2015

\begin{abstract}
Opposing theoretical predictions about the effects of trade preferences on multilateral tariff cuts point to the need for empirical analysis to determine whether preferential trade agreements promote or hinder multilateral trade liberalization. This paper examines the impact of Japan's trade preferences on its multi-lateral tariff reductions. Using detailed product level data, we find that Japan's Generalized System of Preferences (GSP) acted as a stumbling block for the country's external tariff liberalization during the Uruguay Round of multi-lateral trade negotiations.
\end{abstract}

JEL: F13, F14.

Keywords: Japan's Generalized System of Preferences; Japan's Most Favoured Nation Tariff changes during the Uruguay Round.

*Corresponding author: Daniel M. Bernhofen, School of International Service, American University, 4400 Massachusetts Ave NW, Washington DC 20016, Phone: 001-202-885-6721, , email: dbernhof@american.edu. 


\section{Introduction}

The dramatic rise of the number of preferential trade agreements (PTAs) during the last two decades has raised a question about the impact of PTAs on multilateral trade liberalization (MTL). ${ }^{1}$ Assuming different motivations behind PTAs, recent political economy models have shown that PTAs can act either as a 'building block' or a 'stumbling block' for governments' incentives to reduce multilateral tariffs. ${ }^{2}$ The scarce empirical literature, which is characterised by methodological differences as well as differences in underlying policy settings, also shows opposing findings. ${ }^{3}$ So it is not clear whether the different findings are caused by differences in empirical methodologies or by differences in the underlying policy environments.

Our paper adds to the empirical literature on preferential trade agreements by providing the first empirical investigation of the impact of Japan's trade preferences on changes of its Most-favoured Nation (MFN) tariffs during the Uruguay Round. By focusing on Japan, we extend the existing literature to a clear-cut PTA - MTL policy context of nonreciprocal trade preferences granted by a large industrialised country to a set of developing countries, in which significant intra-bloc competition following the PTA formation is likely to have been rather limited. In this paper, and in other work (Ketterer et al., 2014), we argue that the impact of preferences is likely to be affected by the type of trading partner or partners the preferences have been offered to and the associated policy context. Compared to previous evidence on Canada, the European Union and the United States, where trade preferences have often been simultaneously granted to less competitive (developing) and also highly competitive trading partners, Japan represents a quite distinctive policy setting given its exclusive focus on unilateral GSP preferences granted to smaller trading partners before the start of the $21^{\text {st }}$ century.

\footnotetext{
${ }^{1}$ While 124 preferential trade agreements had been notified to the WTO from 1948 to 1994, more than 370 were notified between 1995 and 2011 (www.wto.org).

${ }^{2}$ See Freund and Ornelas (2010) of a recent survey of the literature on PTAs.

${ }^{3}$ Limão (2006) and Karacaovali and Limão (2008) analyse bound multilateral tariff changes of preferentially and non-preferentially traded goods during the Uruguay Round, whereas Bohara et al. (2004), Estevadeordal et al. (2008), and Calvo-Pardo et al. (2010) analyse the relationship between preferential and multilateral tariff changes by regressing applied MFN tariff changes on lagged values of preferential tariff changes in panel data settings using OLS and IV estimators. The former two studies find evidence for preferences hindering further multilateral tariff reductions, whereas the latter studies find evidence for the opposite. In addition, using a crosssectional regression approach Bohara et al. (2004) estimate the influence of Brazil's exports to Argentina on the latter's external tariffs in the presence of Mercosur and find that increasing preferential imports resulted in lower Argentine external tariffs.
} 
In line with the hypothesised importance of the associated policy context, we find empirical evidence for a stumbling block effect of Japan's GSP preferences. ${ }^{4}$ Indeed, the potential for GSP preferences to result in multilateral liberalisation inertia represents a longlasting concern originally voiced by the opponents of the GSP system, when it was first proposed in the 1960s (Johnson, 1967). Moreover, GSP trade preferences have often been found to support diplomatic policy objectives, rather than solely representing altruistic economic development assistance (Komuro, 2009). ${ }^{5}$ The threat of an erosion of preferences, or even their elimination, when liberalising trade multilaterally, may limit the use of preferences as possible leverage for non-trade related objectives, and may reduce preference granting countries' incentives to cut trade barriers multilaterally.

The incentive to exchange preferences for closer diplomatic (i.e. non-trade related) cooperation may result in less aggressive tariff cuts for preferentially traded goods. Valuing the smaller trading partner's closer diplomatic cooperation, Japan may subsequently face an additional constraint on lowering its external tariffs in order to preserve PTA-negotiated preference margins. As a result, Japanese policy makers may have been less aggressive in reducing UR bound external tariffs in the presence than in the absence of GSP trade preferences.

In section 2 we sketch out an analytical framework that highlights how differences in policy environments result in different predictions about how a PTA affects multilateral tariff reductions. Our framework compares the possible 'non-economic policy concession' motive (Limão, 2007) with the rent destruction dimension of a PTA (Ornelas, 2005). The theoretical analysis implies that it is an empirical question to decide which forces are at work, with the possibility that potentially opposing forces result in no effect.

Following a short description of Japan's trade policy and Uruguay Round tariff cuts in section 3, section 4 explains our empirical methodology. In order to estimate the impact of GSP preferences on MFN tariff changes, we use tariff changes on non-GSP goods as the

\footnotetext{
${ }^{4}$ Our empirical evidence of a stumbling block effect of GSP preferences for Japan stands in contrast to Ketterer et al. (2014, Table 3) where we find no stumbling block effect of GSP preferences for Canada in three out of four specifications. We explain this by the difference in policy context, with Japan offering trade preferences only to small, developing countries (at the time of the Uruguay Round).

${ }^{5}$ The use of trade linkages as tools for diplomatic or strategic security objectives has also been acknowledged in an extensive international relations literature, including arguments of preferential trade and global supply chains representing essential cornerstones for political cooperation (see Freidman, 2005, for a more recent account of this literature).
} 
counterfactual for tariff changes in the absence of GSP. Since this identification is the same as in Limão (2006), Karacaovali and Limão (2008) and Ketterer et al. (2014), one can explain differences in results by differences in policy contexts.

Our empirical results, reported in section 5, apply OLS and IV-GMM estimation techniques to estimate the impacts of Japanese trade preferences on 6-digit HS variation in Uruguay Round tariff changes. Our empirical findings are statistically significant and we find larger MFN tariff concessions, of the order of 1.6 to 1.8 percentage points, for non-GSP goods relative to GSP goods. Our results hence identify a significantly larger stumbling block effect for Japan compared to the EU (1.3 to 1.5) and the US (1.0 to 1.3), which we interpret as reflecting the distinctive nature of Japan's GSP-focused PTA policy setting, with the scope for significant rent destruction being absent and the opportunity for non-economic policy motivations being more important. 


\section{Analytical Framework}

We consider a simple conceptual framework that incorporates two principle mechanisms through which trade preferences can promote or hinder external multi-lateral tariff reductions. We nest the 'non-economic concession' motivation of a PTA (Limão, 2007) with the rent destruction potential of a PTA (Ornelas, 2005). We highlight how different assumptions regarding the objectives of a PTA result in different predictions and refer the reader to these original papers for the detailed theoretical treatments.

Consider a three-economy framework, consisting of Home, Foreign and the Rest of the World (ROW), which examines how Home's external tariff formation against ROW is endogenously affected by Home granting preferences to Foreign. Using the standard assumption that each country is a natural importer of a distinct subset of goods and that tariffs are the only instrument of protection, permits us to focus on Home's external import tariff $t$ as the main choice variable for Home's representative import good. In the absence of a preferential trade agreement and any political economy considerations, Home chooses a tariff $\mathrm{t}$ that optimizes national welfare $\mathrm{W}(\mathrm{t})$, defined as the sum of producers' surplus, consumers' surplus and tariff revenue.

In a political economy environment with lobbying from domestic industry and preference granting to Foreign, the Home government maximizes a political objective function $\mathrm{G}$ which is the sum of national welfare W(t), the value of Foreign's cooperation on non-trade issues $\mathrm{e}^{\mathrm{F}}$ and the amount of campaign contributions $\mathrm{T}$ by the import competing domestic industry:

$$
G\left(t, e^{F}, T\right)=W(t)+\lambda_{1} e^{F}+\lambda_{2} T,
$$

where $\lambda_{1}$ and $\lambda_{2}$ are non-negative weights. The political objective function (1) nests the two prototype preferential trade agreements by the parameters $\lambda_{1}$ and $\lambda_{2}$. We can now sketch out the difference between Home's optimal external political tariff in the absence and presence of a PTA, denoted by $t^{\mathrm{p}}$ and $\mathrm{t}^{\mathrm{p}}$ PTA, respectively, and contingent on the type of preferential trade agreement.

If $\lambda_{1}>0$ and $\lambda_{2}=0$; we consider a prototype PTA where Home is not subject to political campaign contributions by import competing sectors and the preferential trade agreement 
affects the government's objective function only through the channel of Foreign's cooperation on non-trade issues $\mathrm{e}^{\mathrm{F}}$. This 'political environment' of a PTA has been modelled by Limão (2007) who has argued that a PTA can be viewed as Home granting trade preferences to Foreign in exchange for Foreign's provision of $\mathrm{e}^{\mathrm{F}}$. Since a reduction of Home's external tariff will reduce (or even eliminate) the value of the preference margin to Foreign, it will reduce Foreign's willingness to provide $\mathrm{e}^{\mathrm{F}}$. This implies that Home's external tariff reductions are predicted to be smaller in the presence than in the absence of a PTA:

$$
\Delta \mathrm{t}^{\mathrm{p}} \mathrm{PTA}^{\mathrm{P}}<\Delta \mathrm{t}^{\mathrm{p}}
$$

The prediction (2) is expected to occur in PTAs where Home is large relative to Foreign and the preference granted to Foreign is in exchange of Foreign's cooperation on non-trade issues such as closer diplomatic ties, strategic defence considerations or the promotion of common standards or regulations (all summarized in $\mathrm{e}^{\mathrm{F}}$ ). The fully specified model of the interaction between such a PTA and Home's external (or multi-lateral) tariff was first articulated by Limão (2007) and later extended by Karacaovali and Limão (2008).

In contrast, if $\lambda_{2}>0$ and $\lambda_{1}=0$, we consider a prototype where the preferential trade agreement affects the government's objective function through its impact on domestic campaign contributions by import-competing sectors. In this setting, campaign contributions are linked to lobbying by import-competing sectors regarding external tariffs and how this lobbying is affected by a PTA. Specifically, Ornelas (2005) has shown that a PTA can reduce lobbying behaviour for tariffs through a "rent destruction effect". Because a PTA reduces tariffs between its members, it provides firms in partner countries with greater access to the home market. Both the increase in foreign competition and the 'leakage of benefits' to PTA partner industries from domestic lobbying for external tariffs will diminish the incentive and the capacity of Home's import-competing sector to lobby. As a result, Home's external tariff reduction is predicted to be higher in the presence than in the absence of a PTA:

$$
\Delta \mathrm{t}^{\mathrm{p}}{ }_{\mathrm{PTA}}>\Delta \mathrm{t}^{\mathrm{p}}
$$

While inequality (2) implies that one should observe higher multi-lateral tariff cuts in 
the absence than in the presence of a PTA, inequality (3) implies just the opposite. So the impact of PTAs on multilateral tariff setting depends on the context of the PTA. Since each prototype PTA suggests a mechanism which operates in an opposite direction, it is possible that both mechanisms are at work in real world PTAs. This implies a possibility of no detectable empirical effect. 


\section{Japan's Preferential Trade Policy and Uruguay Round Tariff Cuts}

\subsection{Japanese Trade Preferences}

Japan's preferential trade policy has been characterized by a strong focus on preferences granted to developing and emerging economies. Until the start of the $21^{\text {st }}$ century, Japan's preferential trading schemes were limited to GSP and LGSP preferences which were first established in 1971 and periodically reviewed thereafter. ${ }^{6}$ While GSP trade preferences mainly granted positive and zero-tariff preferential market access to a range of developing countries on designated products in particular for industrial and mining products, with only a few preferences granted on agricultural goods, LGSP trade preferences established additional trade concessions in the form of duty free access for almost all imports from the world's poorest economies. ${ }^{7}$ From the early 2000 s onwards and after the Uruguay Round tariff cuts, investigated in this paper, Japan's preferential trade policy changed remarkably (Urata, 2004). In contrast to its previous reluctance to grant additional trade preferences alongside its GSP systems, Japan started to sign several bilateral economic partnership agreements (EPAs) with the conclusion of 13 bilateral EPAs by the end of $2011 .^{8}$

Analysing Japan's external tariff policy during the Uruguay Round (1986-1994), we focus in our empirical analysis on Japanese preferences granted or in place at the time of the final UR negotiations and thus on preferences granted under the country's GSP or LGSP systems. Despite having been introduced in the GATT's trade policy framework for development reasons, these preferential schemes have also been found to be used to support

\footnotetext{
${ }^{6}$ Japan revised its GSP system four times until 2011. The respective starting dates of the decennial schemes were 1981, 1991 and 2001 (Komuro, 2009).

${ }^{7}$ In our dataset there are 1336 product lines covered by GSP trade preferences and only around 22 which were additionally part of the LGSP system. In 1994, 149 products were imported from a least developed country (LDC), while 2275 products were imported from the group of GSP countries. Note that in our empirical investigation we use an interaction variable combining product-level information on preferences granted and actual imports from the respective preference receiving country.

${ }^{8}$ Japan concluded its first EPA with Singapore in 2002 and further economic partnership agreements (EPAs) with Mexico, Malaysia, the Philippines, Chile and Thailand followed in rapid succession. Until the end of 2011 Japan concluded 13 bilateral EPAs, including trade concessions granted to ASEAN countries and India. In addition to mutual preferential market access concessions, Japan's EPA policy further includes strong elements of economic and non-economic cooperation such as common regulations on investment rules, competition laws as well as environment-, and energy-conservation. For more detailed information of EPAs in the East-Asian region see Kawai and Wignaraja (2008). The bilateral Japan-Singapore Economic Partnership Agreement (EPA) entered into force in 2002, the Japan-Mexico and Japan-Malaysia EPAs in 2005 and 2006 respectively, while Japan's EPAs with Chile and Thailand were enforced in 2007, and the one with the Philippines in 2008. Further agreements were concluded with Indonesia, Brunei, ASEAN, Vietnam (all in 2008) as well as with Switzerland (2009), India and Peru (both 2011). In addition, Annex Figure 1 provides a brief graphical overview of Japan's aggregated GSP/LGSP and MFN tariff evolution over time. The latter tends to point to a five-year phasing-in period for most of the UR negotiated tariff cuts and a relatively small difference between the applied and bound MFN tariffs thereafter.
} 
national policy-makers' "short-term nationalistic political objectives that are not materially related to overall economic development" (Jackson, 1997:160). Employed as diplomatic 'bargaining chips' for the government's non-trade related policy objectives, trade preferences, in particular when not based on mutual market access concessions, may therefore be seen as components of trade- as well as foreign-policy instruments (Komuro, 2009). Developed countries granting preferential market access to less developed trading partners may therefore have an incentive to maintain these preferences and oppose excessive multilateral liberalisation, as they can be employed as possible side payments for closer noneconomic political cooperation (Limão and Olarreaga, 2006). Japan's penchant to use trade preferences as a complement to foreign policy objectives may be hinted at by the Japanese Council of Ministers recent statement on the policy objectives of Economic Partnership Agreements which highlights the latters" role in promoting the "creation of [an] international environment beneficial to our country" and to "strengthen our economic power and [ability to] tackle political and diplomatic challenges". 9

\subsection{Uruguay Round Tariff Concessions}

Multilateral trade negotiations in the Uruguay Round (UR) started in 1986 and lasted until 1994. More than 100 participating countries agreed to legally binding tariff cuts on numerous goods including concessions negotiated in so-called sectoral agreements (e.g. textile, chemicals etc.). In order to achieve an informal tariff reduction aim of one third, participating countries were asked to submit 'line-by-line' reduction proposals as a starting point for further negotiations. ${ }^{10}$

Table 1 provides an illustration of Japan's bound ad-valorem MFN tariff rates before and after the UR as well as the agreed cuts per industry. The sectors with the largest average tariff protection before and after the Uruguay Round were the beverage, processed food and tobacco industries. In addition, several industries showed (rather low) average protection

\footnotetext{
${ }^{9}$ For more information see Ministry of Economy, Trade and Industry (METI), (2005:4).

${ }^{10}$ While during preceding multilateral trade rounds (e.g. Tokyo Round) the application of so-called 'formula approaches' used to be common practise (cf. GATT Article 28 bis), the UR failed to reach a common consensus on mutually acceptable reduction modalities. While the United States favoured an item-by-item approach, other participants were opposed since they feared that the latter approach would allow for continuing high protection in certain sectors (WTO, 2005). The GATT contracting parties finally agreed to reduce their tariffs "with a target amount of overall reductions at least as ambitious as that achieved by the [Swiss-] formula participants in the Tokyo Round" (WTO, 2005), a statement that was generally interpreted as an overall tariff reduction of $33.3 \%$ (Hoda, 2001; WTO, 2005).
} 
rates of around 4 percentage points before the Round, including the paper, printing, petroleum, machinery and transport equipment industries; most of which are characterized by even lower rates or duty-free access after the UR negotiations (Table 1, Columns 2 and 3).

The largest average tariff cuts were experienced in the processed food and beverage industries. With sector-level reductions of 7 and 14 percentage points, respectively, the latter were clearly above the average cut across all industries of around 4 percentage points (Table 1, Column 3). Analysing Japan's Uruguay Round tariff concessions as a percent of initial (i.e. pre-UR) bound rates, rather than percentage points, identifies the paper, printing, machinery, transport and scientific equipment industries as the sectors with tariff cuts above 95 percent, whereas the tobacco industry was characterized by the lowest average tariff reductions of around 17 percent (Table 1, Column 5). Coefficients of variation also displayed in Table 1, Column (4), further point to the presence of significant variations regarding the magnitude of the product-level MFN tariff cuts within individual industries. Finally, comparing actual with the one third hypothetical reductions (Table 1, Column 4 and 6, respectively), also reveals that the tariff cuts were not uniformly applied across different industries to achieve the informal reduction target. 


\begin{tabular}{|c|c|c|c|c|c|c|c|c|c|c|c|}
\hline \multirow[b]{3}{*}{$\begin{array}{l}\text { ISIC } \\
\text { code }\end{array}$} & \multirow[b]{3}{*}{ Sector name } & \multirow{3}{*}{$\begin{array}{l}(1) \\
\\
\text { Tariff Lines }\end{array}$} & \multicolumn{2}{|l|}{ (2) } & \multicolumn{2}{|l|}{ (3) } & \multicolumn{3}{|l|}{ (4) } & \multirow{2}{*}{$\begin{array}{l}\text { (5) } \\
\text { Uruguay Round Tariff } \\
\text { Cuts (Percent) }\end{array}$} & \multirow{2}{*}{$\begin{array}{l}(6) \\
\text { Hypothetical } \\
\text { 1/3reduction target }\end{array}$} \\
\hline & & & \multicolumn{2}{|l|}{$\begin{array}{l}\text { Before } \\
\text { Round }\end{array}$} & $\begin{array}{l}\text { After } \\
\text { Round }\end{array}$ & Uruguay & \multicolumn{2}{|c|}{$\begin{array}{l}\text { Uruguay Round } \\
\text { (Percentage Points) }\end{array}$} & \multirow{2}{*}{$\begin{array}{l}\text { Tariff Cuts } \\
\text { Coef. Var. }\end{array}$} & & \\
\hline & & & Mean & Std. dev. & Mean & Std. dev. & Mean & Std. dev. & & $\begin{array}{l}\text { Mean } \\
\text { (\% of pre-UR rates) }\end{array}$ & $\begin{array}{l}\text { Mean } \\
\text { (percentage points) }\end{array}$ \\
\hline 311 & Food products & 87 & 0.19 & 0.21 & 0.12 & 0.12 & -0.07 & 0.10 & 1.41 & -37.9 & -0.13 \\
\hline 313 & Beverages & 4 & 0.25 & 0.18 & 0.11 & 0.08 & -0.14 & 0.11 & 0.73 & -56.2 & -0.17 \\
\hline 314 & Tobacco & 2 & 0.15 & 0.07 & 0.12 & 0.05 & -0.03 & 0.02 & 0.64 & -17.5 & -0.10 \\
\hline 321 & Textiles & 148 & 0.09 & 0.05 & 0.06 & 0.03 & -0.04 & 0.02 & 0.66 & -40.5 & -0.06 \\
\hline 322 & Wearing apparel except footwear & 68 & 0.11 & 0.03 & 0.07 & 0.03 & -0.03 & 0.01 & 0.43 & -34.9 & -0.07 \\
\hline 323 & Leather products & 20 & 0.09 & 0.05 & 0.07 & 0.07 & -0.02 & 0.02 & 0.82 & -40.6 & -0.06 \\
\hline 324 & Footwear except rubber or plastics & 2 & 0.07 & 0.04 & 0.06 & 0.03 & -0.01 & 0.01 & 0.54 & -20.5 & -0.05 \\
\hline 331 & Wood products except furniture & 20 & 0.07 & 0.06 & 0.03 & 0.02 & -0.05 & 0.05 & 0.97 & -59.9 & -0.05 \\
\hline 332 & Furniture except metal & 16 & 0.05 & 0.00 & 0.01 & 0.02 & -0.04 & 0.01 & 0.36 & -79.2 & -0.03 \\
\hline 341 & Paper and products & 86 & 0.04 & 0.02 & 0.00 & 0.01 & -0.04 & 0.02 & 0.43 & -96.3 & -0.03 \\
\hline 342 & Printing and publishing & 11 & 0.04 & 0.00 & 0.00 & 0.00 & -0.04 & 0.00 & 0.04 & -100.0 & -0.03 \\
\hline 351 & Industrial chemicals & 464 & 0.06 & 0.02 & 0.03 & 0.02 & -0.02 & 0.01 & 0.68 & -40.0 & -0.04 \\
\hline 352 & Other chemicals & 137 & 0.06 & 0.02 & 0.01 & 0.03 & -0.04 & 0.02 & 0.46 & -79.6 & -0.04 \\
\hline 353 & Petroleum refineries & 13 & 0.04 & 0.02 & 0.02 & 0.02 & -0.02 & 0.01 & 0.33 & -63.8 & -0.02 \\
\hline 354 & Miscellaneous petroleum and coal products & 3 & 0.04 & 0.01 & 0.01 & 0.01 & -0.03 & 0.02 & 0.59 & -77.1 & -0.03 \\
\hline 355 & Rubber products & 37 & 0.05 & 0.01 & 0.01 & 0.01 & -0.04 & 0.01 & 0.33 & -84.9 & -0.03 \\
\hline 356 & Plastic products & 42 & 0.07 & 0.04 & 0.05 & 0.04 & -0.02 & 0.01 & 0.46 & -38.0 & -0.05 \\
\hline 361 & Pottery china earthenware & 12 & 0.04 & 0.00 & 0.01 & 0.01 & -0.03 & 0.01 & 0.37 & -77.2 & -0.03 \\
\hline 362 & Glass and products & 46 & 0.05 & 0.02 & 0.01 & 0.02 & -0.04 & 0.01 & 0.26 & -81.7 & -0.03 \\
\hline 369 & Other non-metallic mineral products & 51 & 0.04 & 0.01 & 0.01 & 0.01 & -0.03 & 0.01 & 0.47 & -68.6 & -0.03 \\
\hline 371 & Iron and steel & 137 & 0.05 & 0.01 & 0.00 & 0.01 & -0.05 & 0.01 & 0.24 & -94.3 & -0.04 \\
\hline 372 & Non-ferrous metals & 87 & 0.06 & 0.03 & 0.03 & 0.02 & -0.03 & 0.01 & 0.37 & -58.0 & -0.04 \\
\hline 381 & Fabricated metal products & 214 & 0.05 & 0.01 & 0.01 & 0.01 & -0.04 & 0.01 & 0.37 & -81.0 & -0.03 \\
\hline 382 & Machinery except electrical & 344 & 0.05 & 0.01 & 0.00 & 0.01 & -0.05 & 0.01 & 0.18 & -97.7 & -0.03 \\
\hline 383 & Machinery electric & 154 & 0.04 & 0.01 & 0.00 & 0.01 & -0.04 & 0.01 & 0.29 & -95.7 & -0.03 \\
\hline 384 & Transport equipment & 89 & 0.04 & 0.01 & 0.00 & 0.00 & -0.04 & 0.01 & 0.25 & -100.0 & -0.03 \\
\hline 385 & Professional and scientific equipment & 130 & 0.05 & 0.01 & 0.00 & 0.01 & -0.05 & 0.01 & 0.19 & -97.4 & -0.03 \\
\hline \multirow[t]{2}{*}{390} & Other manufactured products & 108 & 0.05 & 0.02 & 0.02 & 0.02 & -0.03 & 0.01 & 0.38 & -68.8 & -0.03 \\
\hline & Total & 2532 & 0.07 & 0.03 & 0.03 & 0.03 & -0.04 & 0.02 & 0.51 & -67.4 & -0.05 \\
\hline
\end{tabular}

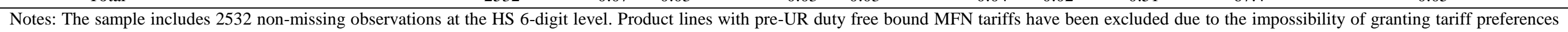

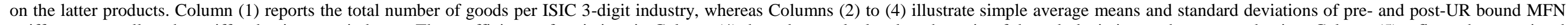

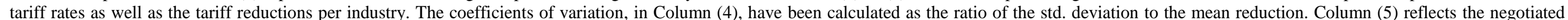

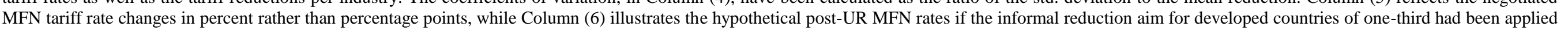
to each industry. 


\section{Empirical Methodology}

\subsection{Identification and Estimating Equation}

Equations (2) and (3) make opposite predictions about the effects of trade preferences on external tariff changes. Because it is not possible to observe changes in external tariffs both in the presence and absence of trade preferences, we follow Limão (2006) in exploiting external tariff changes on non-PTA goods as the counterfactual for external tariff changes in the absence of a PTA. Equation (2) seeks to capture the scope for differential external tariff cuts for non-GSP goods relative to GSP goods (i.e. preferentially imported products).

Our estimating equation aims to explain product level changes in Japan's external tariff cuts during the Uruguay Round ${ }^{11}$ :

$$
\Delta \mathrm{t}_{\mathrm{i}}=\beta_{1} \mathrm{I}_{\mathrm{i}}+\beta_{2} \mathrm{R}_{\mathrm{i}}+\beta_{3} \mathrm{P}_{\mathrm{i}}+\beta_{4} \Delta \mathrm{X}_{\mathrm{h}}+\beta_{5} \mathrm{t}_{\mathrm{i}, \mathrm{t}-1}+\mu_{\mathrm{i}}
$$

Our dependent variable $\Delta \mathrm{t}_{\mathrm{i}}$ is the change in Japan's negotiated bound MFN tariff during the Uruguay Round, measured at the 6-digit HS product level. ${ }^{12}$ Our key explanatory variable is the binary variable $\mathrm{I}_{\mathrm{i}}$, which takes the value 1 if a GSP-specific preferential tariff was granted for product $i$ and if the product was also imported, otherwise it is $0 .{ }^{13}$ Given the policy context, we hypothesize a positive sign for $\mathrm{I}_{\mathrm{i}}$, which would imply a stumbling block effect and smaller tariff cuts for GSP than non-GSP goods.

In addition, we include a series of control variables that account for other factors that might impact multilateral tariff negotiations and which have also been considered in previous studies in the literature. ${ }^{14}$ The variable $\mathrm{R}_{\mathrm{i}}$ aims to capture Japanese tariff concessions that are motivated by reciprocity in tariff negotiations with its main trading partners. This variable is defined as a proxy measure for Japan's reciprocal tariff concessions under the WTO's reciprocity principle and is calculated as $\mathrm{R}_{\mathrm{i}}=\sum_{\mathrm{k}} \mathrm{s}_{\mathrm{it}}{ }^{\mathrm{k}}\left[\sum_{\mathrm{i}} \mathrm{W}_{\mathrm{i}}{ }^{\mathrm{k}} \Delta \mathrm{t}_{\mathrm{i}}{ }^{\mathrm{k}} / \mathrm{t}_{\mathrm{i}}{ }^{\mathrm{k}}\right] . \mathrm{R}_{\mathrm{i}}$ is constructed by first averaging the tariff concessions across each product $i$ for a WTO member country $k$ using the corresponding import weight $\mathrm{w}_{\mathrm{i}}{ }^{\mathrm{k}}$ (i.e. $\sum_{\mathrm{i}} \mathrm{W}_{\mathrm{i}}{ }^{\mathrm{k}} \Delta \mathrm{t}_{\mathrm{i}}{ }^{\mathrm{k}} / \mathrm{t}_{\mathrm{i}}{ }^{\mathrm{k}}$ ). Recognizing that that Japan might have

\footnotetext{
${ }^{11}$ This specification can also be found in Limão (2006) and Ketterer et al. (2014).

${ }^{12}$ We have excluded products characterized by a zero MFN tariff prior to the Uruguay Round and also excluded agricultural products because of the prevalence of non-tariff barriers to trade in that sector. This has left us with a total sample of 2532 product lines.

${ }^{13}$ In our estimations we consider GSP-good specifications for Japanese preferences granted under the GSP as well as the LGSP trading schemes. Our binary variable pertains to preferential access in 1993 or 1994.

Following the suggestions of a referee, we also conducted a robustness check by running our benchmark regressions using 1988 preferences and import data. Because we continued to find a statistically significant building block effect, we did not report the results in the paper.

${ }^{14}$ Our specification follows Ketterer et al. (2014).
} 
been only engaged in direct trade talks with its most important import suppliers, we then aggregate over Japan's top-5 import suppliers' using country k's import share in good i $\left(\mathrm{s}_{\mathrm{it}}{ }^{\mathrm{k}}\right)$ as an additional weight. ${ }^{15}$

Reciprocal tariff reductions in combination with the GATT's MFN principle may give rise to an MFN externality effect, with potentially lower tariff cuts in the presence of many smaller trading partners which may benefit from the larger countries' reciprocal concessions without having to offer any reductions by themselves. A sizable number of smaller 'freeriding' trading partners may then result in a reduced willingness to offer substantial concessions on the part of the larger economies since these cannot expect any meaningful reciprocal tariff reductions in return. Because information on Japan's direct negotiating partners is not available, we aim to account for this effect by introducing a variable reflecting the change in Japan's non top-5 exporters per product line i between 1994 and 1989. ${ }^{16}$ Using the change in non top-5 exporters as a proxy for the potential of an MFN externality effect, we define a control variable $\mathrm{P}_{\mathrm{i}}$ as an indicator taking the value one if the latter variation in the number of non-top 5 suppliers is larger than the median change and zero otherwise.

We follow the literature by introducing a control variable $\Delta X_{h}$, which aims to capture the political power of a sector $\mathrm{h}$ in influencing multilateral tariff cuts. This variable is defined as $\Delta \mathrm{X}_{\mathrm{h}}=\Delta\left(\mathrm{X}_{\mathrm{h}} / \mathrm{M}_{\mathrm{h}}\right) / \varepsilon_{\mathrm{h}}$, where $\Delta\left(\mathrm{X}_{\mathrm{h}} / \mathrm{M}_{\mathrm{h}}\right)$ measures the change in the inverse import penetration ratio between the final phase of the Uruguay Round (1992) and the end of the Tokyo Round (1978) and $\varepsilon_{\mathrm{h}}$ represents the corresponding ISIC 3-digit import demand elasticity in sector h. ${ }^{17}$ Our last control variable takes account of the possibility that governments may find it easier to reduce tariffs on products where tariff levels are still quite high. Hence we also add the level of initial (i.e. pre-UR) bound tariffs $t_{i, t-1}$ as a regressor in our estimating equation.

\subsection{Endogeneity Concerns}

A potential endogeneity concern in the context of preferences and multilateral tariff cuts is associated with the possibility of reverse causality. Considering the possibility that countries may be more likely to ask for preferential treatment in products for which they

\footnotetext{
${ }_{16}^{15}$ Note that information on Japan's direct UR negotiating partners in not available.

${ }^{16}$ It is assumed that if the change of small exporters to Japan per product line i was large enough between 1994 and 1989, the latter may mirror a longer term change between 1978 (end-Tokyo) and 1994 (end-Uruguay). The constructed proxy variable is therefore used as an instrument for the MFN externality effect.

${ }^{17}$ The construction of the political economy variable traces its origin from Goldberg and Maggi (1999) and Gawande and Bandyopadhyay (2000). The inverse import penetration ratio has additionally been multiplied by product level import demand elasticities following Ramsey's standard taxation theory.
} 
expect smaller tariff reductions, anticipated MFN tariff changes may influence whether a good receives a preference or not in the first place. In order to control for this we use additional IV-GMM estimation techniques as well as OLS. Using an instrumental variable approach to account for the latter, we employ the dummy indicating whether a product was imported in $1994, D_{i}^{94}$, as an instrument. The rationale behind this instrument is that it is directly related to the preference indicator itself, but likely to be unaffected by the UR tariff cuts. World-price changes between 1992 and 1994 are used as a second instrument for the preference good indicator. Influencing the monetary benefit arising from a preference and thus the demand for preferential market access, world price changes between 1992 and 1994 tend to be uncorrelated with the error term since the UR tariff concessions did not enter into force before $1995 .{ }^{18}$ Finally, given that NTBs may lead to an increase of domestic prices which are also received by preferential exporters in case of a zero-preferential tariff, countries may be more likely to ask for a preference on goods which they expect to be subject to an NTB in the future. Data for 1993 is used as a proxy for future NTBs. ${ }^{19}$

Potential endogeneity concerns due to reverse causality may also affect some of the introduced control variables. Given that Japan's tariff cuts may influence other countries' (reciprocal) tariff reductions, the reciprocity variable may also give rise to reverse causality concerns. Unilateral tariff reductions implemented between 1986 and 1992 are therefore used as an instrument. Most UR-participants reduced their tariffs unilaterally between 1986 and 1992 despite substantial doubts regarding the successful conclusion of the Uruguay Round (Stewart, 1999). Later, during the final phase of the UR, unilateral liberalization efforts were explicitly taken into account when the final cuts were agreed upon (Finger et al., 2002). Following Karacaovali and Limão (2008), we therefore argue that unilateral tariff reductions may serve as a legitimate instrument for the undertaken reciprocal cuts. ${ }^{20}$

\footnotetext{
${ }^{18}$ In light of the fact that a country's financial benefit arising from preferential market access also depends on world prices, the latter may also impact a partner country's desire for preferential market access. Increasing world prices may also help to overcome fixed export costs.

${ }^{19}$ A country may even be more inclined to ask for a preference if it already exported a given product. We therefore interact an NTB indicator variable with an export dummy variable and introduce the combined component as an additional instrument. Moreover, world price changes at the 6-digit HS product-level are proxied by calculating unit-values using import value and quantity information available at UN-TRAINS.

${ }^{20}$ Finger et al. (2002: 121) note that "according to delegations, the informal practice was more or less to count from applied rates in 1986 to the bound rate agreed at the Uruguay Round. By this practice, countries that had, after 1986, unilaterally reduced their tariffs would be given 'credit' at the round to the extent that they bound these cuts at the round."
} 
The political economy variable may also represent a source of potential endogeneity, since the latter's components are all influenced by domestic prices and therefore by external tariffs. In order to account for this we employ the difference in industry-level scale economies (i.e. valued added/number of firms) between 1981 and 1992 as an instrument, on the grounds that larger economies of scale may point to higher fixed entry costs and therefore a higher inverse import penetration ratio. Combining the industry-level scale economies with the product-level, world price change (between 1992 and 1994) is finally also used as an additional instrument, given that world prices impact on domestic prices and thus on our political economy proxy but are likely to be uncorrelated with the error term. ${ }^{21}$

\subsection{Data Sources}

We highlight the main features of the data and refer to Annex Tables 1 and 2 for the detailed description and summary statistics of all variables. Our dependent variable is constructed using information on Japan's 6-digit HS Uruguay Round ad-valorem tariff

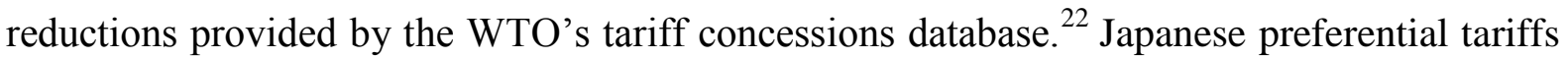
as well as value and quantity information of Japan's import flows, all at the 6-digit HS level, are from the UN-TRAINS database. ${ }^{23}$ NTB data for the year 1993, used as an instrument for the preference indicator variable, was helpfully provided by the Trade Information Department of UNCTAD. ${ }^{24}$ We construct our political economy variable by using import and production data from the UNIDO database and import demand elasticities at the ISIC 3-digit industry level from Kee et al. (2009). Sector level data on the number of establishments and valued added, which were both used to construct an instrument for the political economy variable, also come from the UNIDO database. ${ }^{25}$ Finally, we used data from Finger et al. (2002) to compose a proxy measure for reciprocal tariff reductions. Aggregating importweighted product level UR tariff concessions into country-averages, the latter authors provide a measure for the UR-participating countries' overall tariff concessions. We use this information to compute a product-level reciprocity measure, by multiplying country-averages

\footnotetext{
${ }^{21}$ Note that the UR negotiated tariff reductions took effect from 1995 onwards.

${ }^{22}$ Following the advice of one of the referees, we also conducted our analysis at the 8-digit HS level. But since our findings of the existence of a stumbling block effect were robust to this modification, we did not include the results in the paper.

${ }^{23}$ Note that product-level concordance tables from UN-TRAINS were used to take into account the partial recoding of certain products.

${ }^{24}$ The latter data is publicly not available at UN-TRAINS.

${ }^{25}$ Note that clustering of standard errors at the ISIC 3-digit industry level is used to take into account the different aggregation levels of the political economy variable and its instruments.
} 
from Finger et al. (2002) by 6-digit HS import-shares from Japan's most important suppliers (retrieved from UN-TRAINS).

\section{Estimation Results and Robustness Tests}

\subsection{Main Findings}

Table 2 presents the main regression results using heteroscedasticity-robust OLS and IV-GMM estimation techniques. The results show, in all model specifications, a 'stumbling block' effect, with coefficients that vary between 0.016 and 0.018 and which are all statistically significant at the $1 \%$ level. Providing support for the argument that Japanese trade preferences, in place at the time of the Uruguay Round, hindered further multilateral tariff liberalization, our results point to less aggressive tariff reductions of, on average, 1.6 to 1.8 percentage points for preferentially imported goods than for goods not receiving any preferential treatment or not being imported at all. ${ }^{26}$ Our results therefore are in line with Limão’s (2006) and Karacaovali and Limão's (2008) findings for the US and the EU of a net 'stumbling block' effect when granting preferential market access to smaller trading partners in exchange for a closer political relationship. They are, however, in contrast to our own finding (Ketterer et al., 2014) for Canada and the preferences granted to the USA under CUSFTA.

Comparing the estimation results across different GSP-good definitions shows similar findings for all model specifications displayed in Table 2. Reporting a 'stumbling block' effect of 1.8 percentage points for preferences granted under both, the GSP and LGSP trading schemes, the OLS estimations are corroborated by the respective IV-GMM results which show a slightly smaller, yet still highly significant, effect of about 1.7 percentage points (Table 2, Columns 1 and 5). The results for the respective duty-free tariff preferences granted also tend to support these findings by showing the same parameter estimates (Table 2, Column 2 for OLS and Column 6 for IV-GMM). ${ }^{27}$ Subdividing Japan's preferential trade concessions in individual trading schemes provides further interesting insights. Preferences granted under Japan's GSP system show significant 'stumbling block' coefficients of 0.018 and 0.017 when estimated with OLS and IV-GMM, respectively, both significant at a $1 \%$

\footnotetext{
${ }^{26}$ Moreover, in light of Japanese overall tariff concessions of around 4.5 percentage points for non-PTA goods, and a 3.8 percentage point overall reduction, the detected stumbling block effect also points to a certain economic importance.

${ }^{27}$ The latter points to the relatively large number of duty-free imported preference goods in our sample.
} 
threshold (Table 2, Columns 3 and 9). Duty-free GSP preferences show almost identical results, with a slightly smaller effect when using OLS (Table 2, Column 4 and 7). Analysing the impact of LGSP preferences corroborates these findings by showing a positive 'stumbling block' effect which, however, tends to imprecisely measured when using IV-GMM, and hence is only significant at the usual levels when estimated with OLS (these results are reported in Annex Table 3). ${ }^{28}$

Table 3 reports the results when considering more restrictive definitions of GSPgoods, by taking into account the relative importance of GSP-import flows (Columns 1 to 4 ), and a pre-specified required difference between product-level MFN and preferential tariff rates (i.e. the preferential tariff margin). While external tariff cuts for product lines with significant GSP-import shares may face increasing opposition given their importance for the partner country and the trade-off of preferences for cooperation on non-trade issues, considering a pre-specified difference between the MFN and preferential tariff rates accounts for potential costs when using the preferential tariff rate (and hence the possibility to use the MFN rate despite the presence of a preferential rate). To take these aspects into account Columns (1) to (4) introduce a 5 and 10\% GSP-import share in the GSP-good specification, whereas Columns (5) to (8) consider a classification of GSP goods if the difference between the external and preferential tariff is larger than two percentage points. Overall, the results in Table 3 confirm our previous findings of a stumbling block effect. In fact, the stronger stumbling block effect in some specifications suggests a higher resistance to external tariff cuts for preferentially-traded products which may be considered as important for the preference-receiving trading partner. ${ }^{29}$

The results for the remaining variables, displayed in Table 2 and Table 3, point to a rather weak impact of political economy forces on Japan's Uruguay Round tariff commitments; the latter only being significant when estimated with IV-GMM in Table 2 and 3. Showing statistically significant coefficients, which vary between 0.003 and 0.018 , our

\footnotetext{
${ }^{28}$ The any- and zero-tariff LGSP preference good specifications (Annex Table 3) both show parameter estimates of 0.020 , significant at the $1 \%$ level, when using the OLS estimator, and parameter estimates of 0.028 with IVGMM. Moreover, it is also worth noting that the LGSP results are based on a very small set of PTA goods (covering 22 product lines) which implies that a certain caution is needed when interpreting these results.

${ }^{29}$ Note that the OLS results for the significant import share specifications report slightly smaller coefficients compared to the respective results in table 2 (columns 3 and 7). The magnitude of the coefficients in all other specifications in table 3 is however considerable larger.
} 
findings only provide partial evidence for lower tariff reductions in politically influential sectors. $^{30}$

Consistent evidence for reciprocity based tariff cuts is not found when analysing their impact on Japan's UR tariff concessions. Negative coefficients for some of the preference specifications are found when using IV-GMM estimation techniques, suggesting smaller Japanese tariff reductions on products imported from UR participating countries which themselves implemented larger product-level tariff reductions. Free-riding strategies on the part of other countries also seem to have played a minor role for Japanese policy makers when establishing their own tariff commitments, as indicated by non-significant coefficients for the MFN externality variable in all model specifications.

Finally, initial tariff rates included in the estimation to control for potentially larger tariff cuts on products with initially high tariffs, show highly significant parameter estimates in all model specifications pointing to an important impact of the level of pre-UR bound tariff rates on the final UR tariff concessions. ${ }^{31}$

Statistical robustness tests presented at the bottom of Table 2 and Table 3 point to generally robust findings. ${ }^{32}$ Hansen J-tests of the joint relevance of the instruments point to a high instrument significance in almost all model specifications. ${ }^{33}$ Difference-in-Sargan test statistics analysing the exogeneity of the more endogeneity prone instruments also reject, in most specifications, the correlation hypothesis to the error term. ${ }^{34}$ Moreover, further statistical endogeneity tests, also displayed at the bottom of Table 2 and Table 3, do not indicate severe endogeneity concerns.

\footnotetext{
${ }^{30}$ Note that the results for LGSP preferences, reported in Annex Table 3, show slightly stronger political economy influences which are significant at the $1 \%$ threshold.

${ }^{31}$ Excluding initial tariff rates, or more generally all other control variables, leads to qualitatively identical findings. These results are not included here but are available upon request.

${ }^{32}$ First-stage regression results for the IV-GMM estimations are presented in Annex table 4.

${ }^{33}$ The correlation hypothesis of the second stage error term with the instruments is rejected in all specifications, apart from the LGSP specifications in Annex Table 3.

${ }^{34}$ We follow Ketterer et al. (2014) in choosing the subset of more endogeneity prone instruments and select the instruments which include either NTB data or an import dummy variable.
} 
Table 2: The Impact of Japanese Trade Preferences on Multilateral Tariff Reductions during the Uruguay Round

\begin{tabular}{|c|c|c|c|c|c|c|c|c|}
\hline & \multicolumn{4}{|c|}{ OLS } & \multicolumn{4}{|c|}{ IV-GMM } \\
\hline & (1) & (2) & (3) & (4) & (5) & (6) & (7) & (8) \\
\hline & $\begin{array}{l}\text { GSP \& } \\
\text { LGSP }\end{array}$ & $\begin{array}{l}\text { GSP \& } \\
\text { LGSP } \\
\text { (Duty-Free) }\end{array}$ & GSP & $\begin{array}{l}\text { GSP } \\
\text { (Duty-Free) }\end{array}$ & $\begin{array}{l}\text { GSP \& } \\
\text { LGSP }\end{array}$ & $\begin{array}{l}\text { GSP \& } \\
\text { LGSP } \\
\text { (Duty-Free) }\end{array}$ & GSP & $\begin{array}{l}\text { Duty-Free } \\
\text { GSP }\end{array}$ \\
\hline $\mathrm{I}_{\mathrm{i}}^{\mathrm{j} \ddagger}$ & $\begin{array}{l}0.018 * * * \\
(0.003)\end{array}$ & $\begin{array}{l}0.018 * * * \\
(0.003)\end{array}$ & $\begin{array}{l}0.018 * * * \\
(0.003)\end{array}$ & $\begin{array}{l}0.016^{* * * *} \\
(0.005)\end{array}$ & $\begin{array}{l}0.017 * * * \\
(0.002)\end{array}$ & $\begin{array}{l}0.017 * * * \\
(0.002)\end{array}$ & $\begin{array}{l}0.017 * * * \\
(0.002)\end{array}$ & $\begin{array}{l}0.017 * * * \\
(0.002)\end{array}$ \\
\hline $\mathrm{R}_{\mathrm{i}}^{*}$ & $\begin{array}{l}0.002 \\
(0.006)\end{array}$ & $\begin{array}{l}0.002 \\
(0.006)\end{array}$ & $\begin{array}{l}0.002 \\
(0.006)\end{array}$ & $\begin{array}{l}0.001 \\
(0.007)\end{array}$ & $\begin{array}{l}-0.010 \\
(0.006)\end{array}$ & $\begin{array}{l}-0.010^{*} \\
(0.006)\end{array}$ & $\begin{array}{l}-0.010^{*} \\
(0.006)\end{array}$ & $\begin{array}{l}-0.008 \\
(0.006)\end{array}$ \\
\hline$\Delta \mathrm{X}_{\mathrm{h}}$ & $\begin{array}{l}0.003 \\
(0.002)\end{array}$ & $\begin{array}{l}0.003 \\
(0.002)\end{array}$ & $\begin{array}{l}0.003 \\
(0.002)\end{array}$ & $\begin{array}{l}0.003 \\
(0.002)\end{array}$ & $\begin{array}{l}0.011^{*} \\
(0.006)\end{array}$ & $\begin{array}{l}0.011^{*} \\
(0.006)\end{array}$ & $\begin{array}{l}0.011^{*} \\
(0.006)\end{array}$ & $\begin{array}{l}0.010^{*} \\
(0.005)\end{array}$ \\
\hline $\mathrm{P}_{\mathrm{i}}$ & $\begin{array}{l}-0.001 \\
(0.002)\end{array}$ & $\begin{array}{l}-0.001 \\
(0.002)\end{array}$ & $\begin{array}{l}-0.001 \\
(0.002)\end{array}$ & $\begin{array}{l}-0.001 \\
(0.002)\end{array}$ & $\begin{array}{l}-0.001 \\
(0.001)\end{array}$ & $\begin{array}{l}-0.001 \\
(0.001)\end{array}$ & $\begin{array}{l}-0.001 \\
(0.001)\end{array}$ & $\begin{array}{l}-0.000 \\
(0.001)\end{array}$ \\
\hline$t_{i, t-1}$ & $\begin{array}{l}-0.376 * * * \\
(0.017)\end{array}$ & $\begin{array}{l}-0.376 * * * \\
(0.017)\end{array}$ & $\begin{array}{l}-0.376 * * * \\
(0.017)\end{array}$ & $\begin{array}{l}-0.360 * * * \\
(0.025)\end{array}$ & $\begin{array}{l}-0.334 * * * \\
(0.076)\end{array}$ & $\begin{array}{l}-0.334 * * * \\
(0.074)\end{array}$ & $\begin{array}{l}-0.334 * * * \\
(0.074)\end{array}$ & $\begin{array}{l}-0.326 * * * \\
(0.059)\end{array}$ \\
\hline Constant & $\begin{array}{l}-0.021 * * * \\
(0.005)\end{array}$ & $\begin{array}{l}-0.021 * * * \\
(0.005)\end{array}$ & $\begin{array}{l}-0.021 * * * \\
(0.005)\end{array}$ & $\begin{array}{l}-0.020 * * * \\
(0.006)\end{array}$ & $\begin{array}{l}-0.022 * * * \\
(0.006)\end{array}$ & $\begin{array}{l}-0.022 * * * \\
(0.006)\end{array}$ & $\begin{array}{l}-0.022 * * * \\
(0.006)\end{array}$ & $\begin{array}{l}-0.022 * * * \\
(0.005)\end{array}$ \\
\hline Observations & 2532 & 2532 & 2532 & 2532 & 2532 & 2532 & 2532 & 2532 \\
\hline Number of PTA goods & 1237 & 1226 & 1226 & 1124 & 1237 & 1226 & 1226 & 1124 \\
\hline Hansen's J (p-val.) ${ }^{\mathrm{a}}$ & - & - & - & - & 0.685 & 0.676 & 0.676 & 0.628 \\
\hline C-stat (p-val. $)^{\mathrm{b}}$ & - & - & - & - & 0.660 & 0.657 & 0.657 & 0.630 \\
\hline Endogeneity (p-val.) ${ }^{\mathrm{c}}$ & - & - & - & - & 0.479 & 0.446 & 0.446 & 0.507 \\
\hline Heterosked. (p-val. $)^{d}$ & 0.000 & 0.000 & 0.000 & 0.000 & 0.000 & 0.000 & 0.000 & 0.000 \\
\hline
\end{tabular}

Notes: $*, * *, * * *$ denote the $10 \%, 5 \%, 1 \%$ significance levels, respectively. The estimations reported in Table 2 have been conducted by using heteroskedasticity robust standard errors, clustered at the 3-digit ISIC industry level. Columns (1) to (4) report the OLS estimation results under different Japanese PTA-good specifications. The respective IV-GMM regression results are illustrated in Columns (5) to (8). $\Delta \mathrm{X}_{\mathrm{b}}$ has been re-scaled by 10,000 . The Ftests of instrument exclusion in the first-stage regressions report all rejections either at the $1 \%$ or $5 \%$ significance level and show first-stage F-statistics which are larger than 10 for $\mathrm{I}_{\mathrm{i}}^{\mathrm{j}}$ and $\mathrm{R}_{\mathrm{i}}$. For $\Delta \mathrm{X}_{\mathrm{h}}$ the F-statistics show values of around 2.3. The first-stage regression results for the main specifications are reported in Annex Table 4. (a) Test of over-identifying restrictions using the Sargan-Hansen method which is based on the null hypothesis that the employed instruments are valid instruments - i.e. that the latter are (jointly) not correlated with the second stage error term. (b) Exogeneity test for a subset of instruments (using Difference-in-Sargan/C-statistics) defining the null hypothesis as instrument exogeneity. The tested instruments include: Danyexp, Dntball, Dntball*Danyexp, Dntb, $(\Delta \mathrm{p} 9294) a v g * \Delta$ scale. (c) Testing regressor endogeneity under the null hypothesis that the selected variables are exogenous (i.e. using OLS provides consistent and efficient results). The potentially endogenous regressors are marked with $¥$. (d) Pagan and Hall's heteroskedasticity test for instrumental variable regressions under the null hypothesis of no heteroskedasticity. 
Table 3: GSP Trade Preferences and MFN tariff cuts: Significant GSP Import Shares \& Sizeable Preference Margins

\begin{tabular}{|c|c|c|c|c|c|c|c|c|}
\hline \multicolumn{5}{|c|}{ Significant GSP Import Share } & \multicolumn{4}{|c|}{ Sizeable Preference Margins } \\
\hline & \multicolumn{2}{|c|}{ OLS } & \multicolumn{2}{|c|}{ IV-GMM } & \multicolumn{2}{|c|}{ OLS } & \multicolumn{2}{|c|}{ IV-GMM } \\
\hline & (1) & (2) & (3) & (4) & (5) & (6) & (7) & (8) \\
\hline & $\begin{array}{l}1994 \text { GSP } \\
\text { Import Share } \\
(5 \%)\end{array}$ & $\begin{array}{l}1994 \text { GSP } \\
\text { Import Share } \\
(10 \%)\end{array}$ & $\begin{array}{l}1994 \text { GSP } \\
\text { Import Share } \\
(5 \%)\end{array}$ & $\begin{array}{l}1994 \text { GSP } \\
\text { Import Share } \\
(10 \%)\end{array}$ & $\begin{array}{l}\text { GSP (Pref. } \\
\text { Margin }>2 \%)\end{array}$ & $\begin{array}{l}\text { LGSP (Pref. } \\
\text { Margin }>2 \% \text { ) }\end{array}$ & $\begin{array}{l}\text { GSP (Pref. } \\
\text { Margin }>2 \% \text { ) }\end{array}$ & $\begin{array}{l}\text { LGSP (Pref. } \\
\text { Margin }>2 \%)\end{array}$ \\
\hline \multirow[t]{2}{*}{$\mathrm{I}_{\mathrm{i}}^{\mathrm{j}{ }^{\mathrm{k}}}$} & $0.016 * * *$ & $0.015 * * *$ & $0.026 * * *$ & $0.035 * * *$ & $0.019^{* * *}$ & $0.022 * * *$ & $0.023 * * *$ & 0.016 \\
\hline & $(0.003)$ & $(0.003)$ & $(0.003)$ & $(0.007)$ & $(0.003)$ & $(0.004)$ & $(0.003)$ & $(0.015)$ \\
\hline \multirow[t]{2}{*}{$\mathrm{R}_{\mathrm{i}}^{*}$} & 0.005 & 0.006 & -0.003 & 0.001 & -0.001 & -0.006 & $-0.015^{* * *}$ & $-0.022 * * *$ \\
\hline & $(0.007)$ & $(0.007)$ & $(0.007)$ & $(0.008)$ & $(0.006)$ & $(0.007)$ & $(0.005)$ & $(0.008)$ \\
\hline \multirow[t]{2}{*}{$\Delta \mathbf{x}$} & 0.003 & 0.003 & $0.014 * *$ & $0.014 * * *$ & 0.002 & 0.002 & $0.009 * *$ & $0.018 * *$ \\
\hline & $(0.002)$ & $(0.002)$ & $(0.006)$ & $(0.005)$ & $(0.002)$ & $(0.002)$ & $(0.004)$ & $(0.007)$ \\
\hline \multirow[t]{2}{*}{$\mathrm{P}_{\mathrm{i}}$} & -0.002 & -0.002 & -0.001 & -0.0003 & -0.0004 & $-0.003 * *$ & 0.001 & -0.001 \\
\hline & $(0.002)$ & $(0.002)$ & $(0.001)$ & $(0.001)$ & $(0.002)$ & $(0.002)$ & $(0.001)$ & $(0.002)$ \\
\hline \multirow[t]{2}{*}{$t_{i, t-1}$} & $-0.374 * * *$ & $-0.375 * * *$ & $-0.341 * * *$ & $-0.522 * * *$ & $-0.384 * * *$ & $-0.371 * * *$ & $-0.338 * * *$ & $-0.317 * * *$ \\
\hline & $(0.019)$ & $(0.020)$ & $(0.104)$ & $(0.079)$ & $(0.0124)$ & $(0.024)$ & $(0.049)$ & $(0.066)$ \\
\hline \multirow[t]{2}{*}{ constant } & $-0.016 * *$ & $-0.014 * *$ & $-0.018 * * *$ & -0.007 & $-0.024 * * *$ & $-0.020 * * *$ & $-0.030 * * *$ & $-0.022 * * *$ \\
\hline & $(0.006)$ & $(0.007)$ & $(0.007)$ & $(0.007)$ & $(0.004)$ & $(0.006)$ & $(0.004)$ & $(0.005)$ \\
\hline Adjusted $\mathrm{R}^{2}$ & 0.61 & 0.59 & 0.43 & 0.30 & 0.71 & 0.61 & 0.63 & 0.34 \\
\hline Observations & 2532 & 2532 & 2532 & 2532 & 1763 & 1805 & 1763 & 1805 \\
\hline $\begin{array}{l}\text { Number of FTA } \\
\text { goods }\end{array}$ & 963 & 825 & 963 & 825 & 533 & 13 & 533 & 13 \\
\hline Hansen's J (p-val.) & - & - & 0.803 & 0.840 & - & - & 0.929 & 0.127 \\
\hline C-stat (p-val.) & - & - & 0.707 & 0.739 & - & - & 0.945 & 0.149 \\
\hline $\begin{array}{l}\text { Endogeneity (p- } \\
\text { val.) }\end{array}$ & - & - & 0.436 & 0.341 & - & - & 0.430 & 0.178 \\
\hline Heterosked. (p-val.) & 0.000 & 0.000 & 0.000 & 0.000 & 0.000 & 0.000 & 0.000 & 0.000 \\
\hline
\end{tabular}

Notes. All regressions are based on heteroskedasticity robust standard errors and clustering at the 3 -digit ISIC industry level. *,**,*** illustrate the $10 \%, 5 \%, 1 \%$ significance levels, respectively. The potentially endogenous regressors are marked with $\ddagger$. 


\subsection{Robustness Tests}

Table 4 displays the regression results when subjecting our main findings to a series of robustness tests. Reporting results for OLS as well as IV-GMM estimation techniques, the table shows the findings for the preference good indicator $\left(\mathrm{I}_{\mathrm{i}}\right)$ variable with the other control variables suppressed. ${ }^{35}$ The baseline results from Table 2 (Columns 1 and 5) are replicated in Column 1 for comparison, while the remaining columns illustrate the regression results when subjecting the latter baseline findings to various robustness checks.

In order to account for unobserved industry effects we first include an additional indicator variable at the 1-digit level when using the Harmonized System (HS) product classification. The results, reported in Column (2), confirm our previous findings by showing highly significant, although slightly smaller, coefficients on the indicator variable of 0.014 and 0.015 when estimated with OLS and IV-GMM, respectively.

In light of the so-called sectoral agreements negotiated during the Uruguay Round, we also test whether the stumbling block effect still holds when accounting for a potential alternative tariff reduction rationale by excluding product lines affected by sectoral negotiations. Column (3) reports the results for the so-called 'zero-for-zero' tariff concessions, while Column (4) additionally takes into account the sectoral negotiations on chemicals. With highly significant coefficients of 0.021 and 0.014 (Column 3) as well as 0.022 and 0.026 (Column 4), we continue to find strong support for a stumbling block effect.

The exclusion of the reciprocity variable and its instruments in Column 5 of Table 4 represent a further robustness test by following the structural model more closely. ${ }^{36}$ The results confirm again the previous baseline results from Column 1.

Product lines characterized by NTBs which affect all trading partners may point to the presence of common unobserved product characteristics which in turn may have an impact on the depth of the agreed tariff concessions. As suggested by Karacaovali and Limão (2008), we exclude the set of instruments involving the latter NTB variable. The results corroborate

\footnotetext{
${ }^{35}$ The results for the suppressed variables as well as the first stage regression results for the IV estimations are available upon request.

${ }^{36}$ Note that Karacaovali and Limão’s (2008) theoretical model does not include a reciprocity term in its final estimation equation.
} 
the above findings, with a slightly smaller but still highly significant GSP good coefficient of 0.015 (Column 6, Table 5).

Moreover, in light of diverging distributions of GSP and non-GSP goods across sectors we additionally analyse whether sector-specific features may drive our stumbling block findings by dropping successively single industries. The results, not reported in Table 4 but available upon request, confirm the main findings by showing highly significant 'stumbling block' results when omitting all sectors individually. We also test whether successively dropping the introduced covariates affects the results for our main variable of interest, and find that the stumbling block effect remains highly significant (Annex Table 5).

Finally, given that the maximum value for the absolute change in the MFN tariff rate is zero, indicates that our dependent variable is censored at the value zero. We hence additionally employ a Tobit model for the most significant specifications of our preference indicator variable. The results are reported in Annex Table 6 and strongly support our previous findings by showing, in magnitude and significance level, identical parameter estimates for the main variable of interest. ${ }^{37}$

\section{OLS \& IV-GMM}

\begin{tabular}{|c|c|c|c|c|c|c|}
\hline & (1) & (2) & (3) & (4) & $(5)$ & (6) \\
\hline Robustness test & $\begin{array}{l}\text { GSP \& } \\
\text { LGSP }\end{array}$ & $\begin{array}{l}\text { "HS Industry } \\
\text { Effects" }\end{array}$ & $\begin{array}{l}\text { "Zero-for-Zero" } \\
\text { Sectoral } \\
\text { Agreements }\end{array}$ & $\begin{array}{l}\text { "Zero-for-Zero" } \\
\text { Agreements incl. } \\
\text { Chemicals }\end{array}$ & $\begin{array}{l}\text { Excluding } \\
\text { Reciprocity }\end{array}$ & $\begin{array}{l}\text { Exclude all NTB } \\
\text { instruments }\end{array}$ \\
\hline $\mathrm{I}_{\mathrm{i}}^{\mathrm{OLS}}$ & $\begin{array}{l}0.018 * * * \\
(0.003)\end{array}$ & $\begin{array}{l}0.014 * * * \\
(0.003)\end{array}$ & $\begin{array}{l}0.021 * * * \\
(0.003)\end{array}$ & $\begin{array}{l}0.022 * * * \\
(0.003)\end{array}$ & $\begin{array}{l}0.018 * * * \\
(0.003)\end{array}$ & $\begin{array}{l}- \\
-\end{array}$ \\
\hline $\mathrm{I}_{\mathrm{i}}^{\mathrm{IV}}$ & $\begin{array}{l}0.017 * * * \\
(0.002)\end{array}$ & $\begin{array}{l}0.015 * * * \\
(0.005)\end{array}$ & $\begin{array}{l}0.014 * * * \\
(0.003)\end{array}$ & $\begin{array}{l}0.026 * * * \\
(0.008)\end{array}$ & $\begin{array}{l}0.018 * * * \\
(0.002)\end{array}$ & $\begin{array}{l}0.015^{* * * *} \\
(0.004)\end{array}$ \\
\hline Observations & 2532 & 2532 & 2061 & 1479 & 2532 & 2532 \\
\hline Number of PTA goods & 1237 & 1237 & 1022 & 557 & 1237 & 1237 \\
\hline
\end{tabular}

Notes: Column (1) above reports the baseline regression results from Table 2 (columns 1 and 5), while the additional robustness test findings are display in columns (2) to (6). In all regression concordance tables have been used. Columns (3) and (4) report the findings when tariff lines covered by the so-called 'zero-for-zero' concessions and by the sectoral agreement on chemicals were excluded. The information which we used regarding product coverage of the latter two agreements is based on information provided by the WTO's secretariat (WTO, 2005). Additional tests have been conducted on the basis of excluding individual industries. The latter results (not reported above in Table 4, but available upon request) confirm the reported 'stumbling block' findings. All regressions use heteroskedasticity robust standard errors clustered at the 3-digit ISIC industry level. *, **, *** illustrate the 10\%, 5\%, 1\% significance levels, respectively.

\footnotetext{
${ }^{37}$ It is, in this context, worthwhile to note that only 14 product lines in our sample are characterised by a zero bound MFN tariff rate change.
} 


\section{Conclusions}

The impact of preferential trade agreements (PTAs) on multilateral trade liberalisation (MTL) is still subject to a controversial debate. In light of an abundant but inconclusive theoretical literature and scarce empirical evidence on the subject matter, we provide new theory-based evidence for an important developed Asian economy - i.e. Japan. By focusing on Japan's external tariff liberalisation agreed upon during the Uruguay Round, we aim to extend the current empirical literature by using an identification strategy which has been suggested by Limão (2006). Analysing negotiated tariff cuts for GSP and non-GSP goods and controlling for a broad range of other factors, we find larger tariff reductions for goods not imported under preferential market access (i.e. non-GSP goods) after having controlled for other influences. Our findings show that tariff concessions on non-GSP goods were on average 1.6 to 1.8 percentage points larger than those for preferentially imported goods.

In light of Japan's strong focus on unilateral GSP preferences granted to smaller trading partners before the start of the $21^{\text {st }}$ century, our findings provide support for the argument that this was a PTA policy-setting in which preferential market access was granted in exchange for a closer political cooperation in general, rather than where rent destruction was at stake. This PTA-setting induced a net 'stumbling block' effect on the setting of Japan's multilateral tariffs during the Uruguay Round, with smaller tariff reductions being implemented on preferentially imported products in order to preserve previously negotiated preference margins and thus in turn to preserve the partner countries' incentives for a continuing commitment towards the non-trade based political objectives they had agreed to with Japan in return for preferences.

Our present findings are in line with previous empirical evidence on the US and the EU which are both characterized by PTAs formed with smaller trading partners including requirements on non-trade related political issues (Limão, 2006; Karacaovali and Limão, 2008). ${ }^{38}$ Our present findings are, however, in contrast with Ketterer et al. (2014) for Canada in the context of the Canadian US free trade agreement. We explain the different findings by the difference in the preferential trade policy setting. In the present study we are exploring the effects of preferences given by a large industrial country to small developing trade partners. In the case of Canada, Ketterer et al. (2014) examine the effect on MFN tariffs of Canadian

\footnotetext{
${ }^{38}$ Examples of such agreements for the USA include the US-Andean Trade Preference Act (ATPA) and the Caribbean Basin Initiative (CBI) as well as the former's GSP trading schemes. PTAs formed by the European Union explicitly incorporating non-trade related policy objectives include, among others, the EU's Euro-Mediterranean (MED), African, Caribbean and Pacific (ACP) and the GSP preferential trading schemes.
} 
preferences granted to the USA (namely a large industrial, trading partner) under CUSFTA. In the context of Canadian preferences granted to the USA, rent destruction in Canadian markets resulting from greater competition from US imports was to be expected. By contrast, Japan's preferences granted to small developing countries were not likely to affect rents in Japan's domestic market. Our expectation that the motivation for PTAs is important in determining whether PTAs act as a hindrance to or support for multilateral liberalisation is confirmed by the present findings. 


\section{REFERENCES}

Bohara, A., Gawande K., Sanguinetti P., 2004, Trade diversion and declining tariffs: evidence from Mercosur, Journal of International Economics, 64, 65-88.

Calvo-Pardo, H., Freund, C., Ornelas, E., 2010, The ASEAN Free Trade Agreement: Impact on Trade Flows and External Trade Barriers, in R. Barro and J. Lee (Eds.), Costs and Benefits of Regional Economic Integration .Oxford University Press, Oxford.

Estevadeordal, A., Freund, C., Ornelas, E., 2008, Does regionalism affect trade liberalization towards non-members?, Quarterly Journal of Economics, 123, 1531-1575.

Finger, M.J., Reincke, U., Castro, A., 2002, Market access bargaining in the Uruguay Round: how tightly does reciprocity constrain? In Bhagwait J., Going alone: The Case for Relaxed Reciprocity in Freeing Trade, MIT Press, London, 2002.

Freund, C., Ornelas, E., 2010, Regional trade agreements, Annual Review of Economics, Annual Reviews, 2(1), 139-166.

Friedman, T., L., 2006, The World is Flat: The Globalized World in the Twenty-First Century, London: Penguin.

Gawande, K., Bandyopadhyay, U., 2000, Is protection for sale? Evidence on the Grossman-Helpman theory of endogenous protection, Review of Economics and Statistics 82 (1), 139-152.

Goldberg, P.K., Maggi, G., 1999, Protection for sale: an empirical investigation, American Economic Review 89 (5), 1135-1155.

Hoda, A., 2001, Tariff Negotiations and Renegotiations under the GATT and the WTO: Procedures and Practices, Cambridge, 2001.

Jackson, J., 1997, The World Trading System: Law and Policy of International Economic Relations. 2nd edition. MIT Press, Cambridge MA.

Johnson, H., G., 1967, Economic Policies toward Less Developed Countries. Washington, D.C.: Brookings Institution.

Karacaovali, B., Limão N., 2008, The clash of liberalizations: preferential vs. multilateral trade liberalization in the European Union, Journal of International Economics, 74, 299-327.

Kawai, M., Wignaraja, G., 2008, Regionalism as an engine of multilateralism: a case for a single East Asian FTA, Working Papers on Regional Economic Integration 14, Asian Development Bank.

Kee, H.L., Nicita, A., Olarreaga, M., 2009, Estimating trade restrictiveness indices, Economic Journal 119, 172-199.

Ketterer, T., Bernhofen, D., Milner, C., 2014, Preferences, Rent Destruction and multilateral liberalization: the building block effect of CUSFTA, Journal of International Economics, 92, 63-77.

Komuro, N., 2009, Japan's Generalized System of Preferences. In Hoekman, B.M., Martin, W., Braga C.A., Trade Preference Erosion: Measurement and Policy Response, World Bank Publications, Washington, 2009.

Limão, N., 2006, Preferential trade agreements as stumbling blocks for multilateral trade liberalization: evidence for the U.S., American Economic Review 96, 896-914. 
Limão, N., 2007, Are preferential trade agreements with non-trade objectives a stumbling block for multilateral liberalization? Review of Economic Studies 74 (3), 821-855.

Ministry of Economy, Trade and Industry (METI), 2005, Japan's Policy on FTAs/EPAs, Tokyo.

Ornelas, E., 2005, Rent destruction and the political viability of free trade agreements, Quarterly Journal of Economics 120, 1475-506.

Stewart, T., 1999, The GATT Uruguay Round: A Negotiation History (1986-1992), Volume 3, Kluwer Law and Taxation Publishers, Deventer (The Netherlands).

Urata, S., 2004, The emergence and proliferation of free trade agreements in East Asia, Japanese Economy, 32(2), 5-52.

World Trade Organisation (WTO), 2005, Document Series: MTN.GNG/NG1/W, WTO, Geneva. 


\section{ANNEX}

Annex Table 1: Summary Statistics

\begin{tabular}{|c|c|c|c|c|}
\hline Variable & Mean & Std. Dev. & Min & Max \\
\hline$\Delta t_{i}$ & -0.04 & 0.03 & -0.43 & 0.00 \\
\hline $\mathrm{I}_{\mathrm{i}}^{\text {any }}$ & 0.49 & 0.50 & 0 & 1 \\
\hline $\mathrm{I}_{\mathrm{i}}^{\text {any0 }}$ & 0.48 & 0.50 & 0 & 1 \\
\hline $\mathrm{I}_{\mathrm{i}}{ }^{\mathrm{gsp}}$ & 0.48 & 0.50 & 0 & 1 \\
\hline $\mathrm{I}_{\mathrm{i}}{ }^{\mathrm{gsp} 0}$ & 0.44 & 0.50 & 0 & 1 \\
\hline $\mathrm{I}_{\mathrm{i}}^{\operatorname{lgsp}}$ & 0.01 & 0.09 & 0 & 1 \\
\hline $\mathrm{I}_{\mathrm{i}}^{\operatorname{lgsp} 0}$ & 0.01 & 0.09 & 0 & 1 \\
\hline$\Delta \mathrm{X}_{\mathrm{h}}$ & -0.69 & 0.98 & -7.74 & 0.20 \\
\hline $\mathrm{R}_{\mathrm{i}}$ & -0.49 & 0.11 & -0.96 & 0.00 \\
\hline $\mathrm{D}_{\text {iany }}{ }^{94}$ & 0.90 & 0.30 & 0 & 1 \\
\hline $\mathrm{D}_{\mathrm{igsp}}{ }^{94}$ & 0.90 & 0.30 & 0 & 1 \\
\hline $\mathrm{D}_{\text {ilgsp }}{ }^{94}$ & 0.06 & 0.24 & 0 & 1 \\
\hline $\mathrm{R}_{\mathrm{i}}^{\mathrm{uni}}$ & -0.26 & 0.11 & -0.92 & 1 \\
\hline $\mathrm{D}^{\mathrm{ntb}}$ & 0.30 & 0.46 & 0 & 1 \\
\hline $\mathrm{D}^{\mathrm{ntball}}$ & 0.30 & 0.46 & 0 & 1 \\
\hline $\mathrm{D}^{\text {ntball }} * \mathrm{D}_{\mathrm{i}}^{94}$ & 0.26 & 0.44 & 0 & 1 \\
\hline $\mathrm{D}^{\mathrm{ntball}} * \mathrm{D}^{\mathrm{gsp}}$ & 0.26 & 0.44 & 0 & 1 \\
\hline $\mathrm{D}^{\mathrm{ntball}} * \mathrm{D}^{\operatorname{lgsp}}$ & 0.01 & 0.11 & 0 & 1 \\
\hline$\Delta \mathrm{p}_{9294}$ & 0.05 & 0.15 & -0.07 & 0.79 \\
\hline$\Delta$ scale & 43.28 & 60.00 & -55.44 & 1120.58 \\
\hline$P_{i}$ & 0.44 & 0.50 & 0 & 1 \\
\hline$t_{i, t-1}$ & 0.06 & 0.05 & 0.01 & 0.93 \\
\hline
\end{tabular}


Annex Table 2: Description of Variables and their Sources when analysing UR bound tariff Changes

\begin{tabular}{|c|c|c|c|}
\hline Variable & Abbreviation & Exact definition & Source \\
\hline \multicolumn{4}{|c|}{ Dependent variable } \\
\hline $\begin{array}{l}\text { Bound MFN tariff rate } \\
\text { reductions }\end{array}$ & $\Delta \mathrm{t}_{\mathrm{i}}$ & $\begin{array}{l}\text { Reduction in bound 'Most Favoured Nation' (MFN) tariffs } \\
\text { negotiated during the Uruguay Round and those in place } \\
\text { before the Uruguay Round (i.e. Tokyo Round). }\end{array}$ & $\begin{array}{l}\text { WTO + authors' } \\
\text { own calculations }\end{array}$ \\
\hline \multicolumn{4}{|c|}{ Explanatory variables } \\
\hline PTA good variable & $\mathrm{I}_{\mathrm{i}}^{\mathrm{j}}$ & $\begin{array}{l}\text { Indicator variable taking the value one if a product was } \\
\text { granted (duty-free) preferential access PTAs in } 1993 \text { or } \\
1994 \text { and was imported by Japan in } 1994 \text { (from the } \\
\text { respective partner country j). }\end{array}$ & TRAINS \\
\hline $\begin{array}{l}\text { Reciprocity induced } \\
\text { changes in market access }\end{array}$ & $\mathrm{R}_{\mathrm{i}}$ & $\begin{array}{l}\text { Import weighted percentage tariff reductions of Japan's } \\
\text { principal suppliers between } 1986 \text { and } 1994 \text { multiplied by } \\
\text { good i's export share of each principal supplier to Japan; } \\
\text { finally aggregation over all principal suppliers of good i. }\end{array}$ & $\begin{array}{l}\text { Finger et al. (2002) } \\
+ \text { TRAINS + } \\
\text { authors' own } \\
\text { calculations }\end{array}$ \\
\hline Political economy variable & $\Delta \mathrm{X}_{\mathrm{h}}$ & $\begin{array}{l}\text { Change in the elasticity weighted inverse import } \\
\text { penetration ratio at an ISIC 3-digit industry level between } \\
1978 \text { (final phase Tokyo Round) and } 1992 \text { (final phase } \\
\text { Uruguay Round). }\end{array}$ & $\begin{array}{l}\text { COMTRADE + } \\
\text { UNIDO + Kee et al } \\
\text { (2009) + authors' } \\
\text { own calculations }\end{array}$ \\
\hline MFN externality variable & $\mathrm{P}_{\mathrm{i}}$ & $\begin{array}{l}\text { Change in the share of small exporters (i.e. non-top } 5 \\
\text { exporters/suppliers) of product } \mathrm{i} \text { between } 1989 \text { and } 1994 . \\
\mathrm{P}_{\mathrm{i}} \text { takes the value one if the above mentioned change is } \\
\text { larger than the median change and zero otherwise. }\end{array}$ & $\begin{array}{l}\text { TRAINS + authors' } \\
\text { own calculations }\end{array}$ \\
\hline \multicolumn{4}{|c|}{ Instruments } \\
\hline Import dummy variable & $\mathrm{D}_{\mathrm{i}}^{\text {any94 }}$ & $\begin{array}{l}\text { Dummy variable indicating whether a product was } \\
\text { imported by Japan from the respective trading partner } \mathrm{j} \text {; } \\
\text { regardless of its 'PTA-status' (instrumental variable for } \mathrm{I}_{\mathrm{i}}^{\mathrm{j}} \text { ). }\end{array}$ & $\begin{array}{l}\text { TRAINS + authors' } \\
\text { own calculations }\end{array}$ \\
\hline NTB dummy variable & $\mathrm{D}_{\mathrm{i}}^{\mathrm{ntb93}}$ & $\begin{array}{l}\text { Dummy variable taking the value one if product } i \text { was } \\
\text { subjected to an NTB in } 1993 \text { (instrumental variable for } I_{i}^{j} \text { ). }\end{array}$ & $\begin{array}{l}\text { TRAINS + authors' } \\
\text { own calculations }\end{array}$ \\
\hline NTB dummy variable & $\mathrm{D}_{\mathrm{i}}^{\text {ntball193 }}$ & $\begin{array}{l}\text { Indicator variable taking the value one if product } \mathrm{i} \text { was } \\
\text { subjected to an NTB in } 1993 \text { which applied to all trading } \\
\text { partners (instrumental variable for } \mathrm{I}_{\mathrm{i}}^{\mathrm{j}} \text { ). }\end{array}$ & $\begin{array}{l}\text { TRAINS + authors' } \\
\text { own calculations }\end{array}$ \\
\hline $\begin{array}{l}\text { NTB \& Import dummy } \\
\text { variable }\end{array}$ & $\mathrm{D}^{\text {ntball93}} * \mathrm{D}^{\text {any } 94}$ & Combination of import and NTB indicator variables. & $\begin{array}{l}\text { TRAINS + authors' } \\
\text { own calculations }\end{array}$ \\
\hline \multirow[t]{2}{*}{ Scale economies } & $\Delta$ scale & $\begin{array}{l}\text { Change in value added/number of firms (establishments) } \\
\text { between } 1981 \text { and } 1992 \text { (instrumental variable for the } \\
\text { political economy variable). }\end{array}$ & $\begin{array}{l}\text { UNIDO + authors' } \\
\text { own calculations }\end{array}$ \\
\hline & $\begin{array}{l}\Delta \text { scale } * \Delta \text { world } \\
\text { price }\end{array}$ & $\begin{array}{l}\text { Interaction of the scale economies instrument with the } \\
\text { average world price change per industry between } 1992 \text { and } \\
1994 \text { (instrumental variable for the political economy } \\
\text { variable). }\end{array}$ & $\begin{array}{l}\text { UNIDO + TRAINS } \\
+ \text { authors' own } \\
\text { calculations }\end{array}$ \\
\hline World prices & $\begin{array}{l}\Delta \text { world price }_{\mathrm{i}}, \\
(\Delta \text { world price })_{\mathrm{i}}{ }^{2} \\
(\Delta \text { world price })_{\mathrm{i}}{ }^{3}\end{array}$ & $\begin{array}{l}\text { HS 6-digit world prices changes calculated as changes in } \\
\text { unit-values between } 1992 \text { and } 1994 \text { (instrumental variable } \\
\text { for } \mathrm{I}_{i}^{\mathrm{j}} \text { ). }\end{array}$ & $\begin{array}{l}\text { TRAINS + authors' } \\
\text { own calculations }\end{array}$ \\
\hline Unilateral tariff reductions & $\mathrm{R}_{\mathrm{i}}^{\text {uni }}$ & $\begin{array}{l}\text { Reciprocity measurement as described above but focusing } \\
\text { on import-weighed unilateral tariff reductions of UR } \\
\text { participants undertaken between } 1986 \text { and } 1992 \text { only } \\
\text { (instrumental variable for } \mathrm{R}_{\mathrm{i}} \text { ). }\end{array}$ & $\begin{array}{l}\text { Finger et al. (2002) } \\
+ \text { TRAINS + } \\
\text { authors' own } \\
\text { calculations }\end{array}$ \\
\hline
\end{tabular}

\footnotetext{
${ }^{39}$ The change in the elasticity weighed inverse import penetration ratio $\Delta \mathrm{X}_{\mathrm{h}}$ is calculated as $\mathrm{x}^{92}-\mathrm{x}^{78}$.

${ }^{40}$ The change in the MFN externality effect or the change in the share of small (non-top5 exporters) of product-

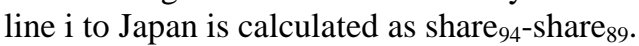


Annex Table 3: Uruguay Bound Tariffs Concessions and LGSP Preferences

\begin{tabular}{|c|c|c|c|c|}
\hline & (1) & (2) & (3) & (4) \\
\hline & LGSP & $\begin{array}{c}\text { Duty-Free } \\
\text { LGSP }\end{array}$ & LGSP & $\begin{array}{l}\text { Duty-Free } \\
\text { LGSP }\end{array}$ \\
\hline$\overline{I_{i}^{j \ddagger}}$ & $\begin{array}{l}0.020 * * * \\
(0.005)\end{array}$ & $\begin{array}{l}0.020 * * * \\
(0.005)\end{array}$ & $\begin{array}{l}0.028 \\
(0.021)\end{array}$ & $\begin{array}{l}0.028 \\
(0.021)\end{array}$ \\
\hline $\mathrm{R}_{\mathrm{i}}^{*}$ & $\begin{array}{l}-0.006 \\
(0.006)\end{array}$ & $\begin{array}{l}-0.006 \\
(0.006)\end{array}$ & $\begin{array}{l}-0.013 * * \\
(0.006)\end{array}$ & $\begin{array}{l}-0.013 * * \\
(0.006)\end{array}$ \\
\hline$\Delta \mathrm{X}_{\mathrm{h}} \dagger$ & $\begin{array}{l}0.003 \\
(0.002)\end{array}$ & $\begin{array}{l}0.003 \\
(0.002)\end{array}$ & $\begin{array}{l}0.018 * * * \\
(0.001)\end{array}$ & $\begin{array}{l}0.018 * * * \\
(0.005)\end{array}$ \\
\hline$P_{i}$ & $\begin{array}{l}-0.003 \\
(0.002)\end{array}$ & $\begin{array}{l}-0.003 \\
(0.002)\end{array}$ & $\begin{array}{l}0.001 \\
(0.002)\end{array}$ & $\begin{array}{l}0.001 \\
(0.002)\end{array}$ \\
\hline$t_{i, t-1}$ & $\begin{array}{l}-0.363 * * * \\
(0.034)\end{array}$ & $\begin{array}{l}-0.363^{* * * *} \\
(0.034)\end{array}$ & $\begin{array}{l}-0.289 * * * \\
(0.069)\end{array}$ & $\begin{array}{l}-0.289 * * * \\
(0.069)\end{array}$ \\
\hline Constant & $\begin{array}{l}-0.017 * * * \\
(0.006)\end{array}$ & $\begin{array}{l}-0.017 * * * \\
(0.006)\end{array}$ & $\begin{array}{l}-0.016^{* * *} \\
(0.005)\end{array}$ & $\begin{array}{l}-0.016^{* * *} \\
(0.005)\end{array}$ \\
\hline Observations & 2532 & 2532 & 2532 & 2532 \\
\hline Number of PTA goods & 22 & 22 & 22 & 22 \\
\hline Hansen's J (p-val.) & - & - & 0.087 & 0.087 \\
\hline C-stat (p-val.) & - & - & 0.097 & 0.097 \\
\hline Endogeneity (p-val.) & - & - & 0.620 & 0.620 \\
\hline Heterosked. (p-val.) & 0.000 & 0.000 & 0.000 & 0.000 \\
\hline
\end{tabular}

Notes: $*, * *, * * *$ denote the $10 \%, 5 \%, 1 \%$ significance levels, respectively. The OLS regression results are displayed in Columns (1) and (2), while the results based on IV-GMM estimation techniques are reported in Columns (3) and (4). All specifications have been estimated using heteroskedasticity robust standard errors, clustered at the 3-digit ISIC industry level. $\Delta X_{h}$ has been re-scaled by 10,000 . The potentially endogenous regressors are marked with $\$$. 
Annex Table 4: $1^{\text {st }}$ Stage IV Results

\begin{tabular}{|c|c|c|c|c|c|c|c|c|c|}
\hline & \multicolumn{3}{|c|}{ GSP \& LGSP Preferences } & \multicolumn{3}{|c|}{ GSP \& LGSP duty-free Preferences } & \multicolumn{3}{|c|}{ GSP Preferences } \\
\hline & $\mathrm{I}_{\mathrm{i}}$ & $\mathrm{R}$ & $\Delta \mathrm{x}$ & $\mathrm{I}_{\mathrm{i}}$ & $\mathrm{R}$ & $\Delta \mathrm{x}$ & $\mathrm{I}_{\mathrm{i}}$ & $\mathrm{R}$ & $\Delta \mathrm{x}$ \\
\hline$\overline{\mathrm{D}_{\mathrm{i}}^{94}}$ & $\begin{array}{l}0.490 * * * \\
(0.109)\end{array}$ & $\begin{array}{l}-0.017 * * \\
(0.006)\end{array}$ & $\begin{array}{l}-0.308 * * \\
(0.144)\end{array}$ & $\begin{array}{l}0.484 * * * \\
(0.108)\end{array}$ & $\begin{array}{l}-0.017 * * \\
(0.006)\end{array}$ & $\begin{array}{l}-0.308 * * \\
(0.144)\end{array}$ & & & \\
\hline$D_{i}^{g s p}$ & & & & & & & $\begin{array}{l}0.484 * * * \\
(0.108)\end{array}$ & $\begin{array}{l}-0.017 * * \\
(0.006)\end{array}$ & $\begin{array}{l}-0.308 * * \\
(0.144)\end{array}$ \\
\hline $\mathrm{D}_{\mathrm{ntb}}^{\text {all }}$ & $\begin{array}{l}-0.155 \\
(0.123)\end{array}$ & $\begin{array}{l}-0.001 \\
(0.001)\end{array}$ & $\begin{array}{l}0.013 \\
(0.268)\end{array}$ & $\begin{array}{l}-0.157 \\
(0.123)\end{array}$ & $\begin{array}{l}-0.006 \\
(0.008)\end{array}$ & $\begin{array}{l}0.013 \\
(0.268)\end{array}$ & $\begin{array}{l}-0.157 \\
(0.123)\end{array}$ & $\begin{array}{l}-0.006 \\
(0.008)\end{array}$ & $\begin{array}{l}0.013 \\
(0.268)\end{array}$ \\
\hline $\mathrm{D}_{\text {ntb }}^{\text {all }} * \mathrm{D}^{94}$ & $\begin{array}{l}0.357 * * * \\
(0.113)\end{array}$ & $\begin{array}{l}-0.001 \\
(0.001)\end{array}$ & $\begin{array}{l}0.046 \\
(0.156)\end{array}$ & $\begin{array}{l}0.362 * * * \\
(0.113)\end{array}$ & $\begin{array}{l}-0.007 \\
(0.008)\end{array}$ & $\begin{array}{l}0.046 \\
(0.156)\end{array}$ & $\begin{array}{l}0.362 * * * \\
(0.113)\end{array}$ & $\begin{array}{l}-0.007 \\
(0.008)\end{array}$ & $\begin{array}{l}0.046 \\
(0.156)\end{array}$ \\
\hline$\Delta$ worldprice & $\begin{array}{l}-0.011 * * \\
(0.045)\end{array}$ & $\begin{array}{l}-0.004 * * * \\
(0.001)\end{array}$ & $\begin{array}{l}-0.005 \\
(3.696)\end{array}$ & $\begin{array}{l}-0.010 * * \\
(0.004)\end{array}$ & $\begin{array}{l}-0.004 * * * \\
(0.001)\end{array}$ & $\begin{array}{l}-0.005 \\
(0.015)\end{array}$ & $\begin{array}{l}-0.010 * * \\
(0.004)\end{array}$ & $\begin{array}{l}-0.004 * * * \\
(0.001)\end{array}$ & $\begin{array}{l}-0.005 \\
(0.015)\end{array}$ \\
\hline$\Delta$ worldprice $^{2}$ & $\begin{array}{l}0.000 \\
(0.000)\end{array}$ & $\begin{array}{l}-0.000 * * \\
(0.000)\end{array}$ & $\begin{array}{l}-0.000 \\
(0.000)\end{array}$ & $\begin{array}{l}0.000 \\
(0.000)\end{array}$ & $\begin{array}{l}0.000 * \\
(0.000)\end{array}$ & $\begin{array}{l}0.000 \\
(0.001)\end{array}$ & $\begin{array}{l}0.000 \\
(0.000)\end{array}$ & $\begin{array}{l}0.000 * \\
(0.000)\end{array}$ & $\begin{array}{l}0.000 \\
(0.001)\end{array}$ \\
\hline$\Delta$ worldprice $^{3}$ & $\begin{array}{l}0.000 \\
(0.000)\end{array}$ & $\begin{array}{l}0.000 \\
(0.000)\end{array}$ & $\begin{array}{l}-0.000 \\
(0.000)\end{array}$ & $\begin{array}{l}0.000 \\
(0.000)\end{array}$ & $\begin{array}{l}0.000 \\
(0.000)\end{array}$ & $\begin{array}{l}0.000 \\
(0.000)\end{array}$ & $\begin{array}{l}0.000 \\
(0.000)\end{array}$ & $\begin{array}{l}0.000 \\
(0.000)\end{array}$ & $\begin{array}{l}0.000 \\
(0.000)\end{array}$ \\
\hline $\mathrm{D}_{\text {ntb }}^{\text {any }}$ & $\begin{array}{l}0.079 \\
(0.089)\end{array}$ & $\begin{array}{l}0.006 \\
(0.004)\end{array}$ & $\begin{array}{l}-0.184 \\
(0.210)\end{array}$ & $\begin{array}{l}0.080 \\
(0.088)\end{array}$ & $\begin{array}{l}0.006 \\
(0.004)\end{array}$ & $\begin{array}{l}-0.184 \\
(0.210)\end{array}$ & $\begin{array}{l}0.080 \\
(0.088)\end{array}$ & $\begin{array}{l}0.006 \\
(0.004)\end{array}$ & $\begin{array}{l}-0.184 \\
(0.210)\end{array}$ \\
\hline$\Delta$ scale-economies & $\begin{array}{l}0.000 \\
(0.000)\end{array}$ & $\begin{array}{l}-0.001 \\
(0.001)\end{array}$ & $\begin{array}{l}0.000 * \\
(0.000)\end{array}$ & $\begin{array}{l}0.000 \\
(0.000)\end{array}$ & $\begin{array}{l}0.000 \\
(0.000)\end{array}$ & $\begin{array}{l}0.000^{*} \\
(0.000)\end{array}$ & $\begin{array}{l}0.000 \\
(0.000)\end{array}$ & $\begin{array}{l}0.000 \\
(0.000)\end{array}$ & $\begin{array}{l}0.000 * \\
(0.000)\end{array}$ \\
\hline $\begin{array}{l}\Delta \text { scale- } \\
\text { eco. }{ }^{*} \text { worldprice }\end{array}$ & $\begin{array}{l}0.000 \\
(0.000)\end{array}$ & $\begin{array}{l}0.000 \\
(0.000)\end{array}$ & $\begin{array}{l}0.000 \\
(0.000)\end{array}$ & $\begin{array}{l}0.000 \\
(0.000)\end{array}$ & $\begin{array}{l}0.000 \\
(0.000)\end{array}$ & $(0.000)$ & $\begin{array}{l}0.000 \\
(0.000)\end{array}$ & $\begin{array}{l}0.000 \\
(0.000)\end{array}$ & $\begin{array}{l}0.000 \\
(0.000)\end{array}$ \\
\hline $\mathrm{R}_{\mathrm{i}}^{\mathrm{uni}}$ & $\begin{array}{l}-0.029 \\
(0.091)\end{array}$ & $\begin{array}{l}0.710 * * * \\
(0.043)\end{array}$ & $\begin{array}{l}0.090 \\
(0.300)\end{array}$ & $\begin{array}{l}-0.016 \\
(0.093)\end{array}$ & $\begin{array}{l}0.710 * * * \\
(0.043)\end{array}$ & $\begin{array}{l}0.091 \\
(0.301)\end{array}$ & $\begin{array}{l}-0.016 \\
(0.093)\end{array}$ & $\begin{array}{l}0.710 * * * \\
(0.043)\end{array}$ & $\begin{array}{l}0.091 \\
(0.301)\end{array}$ \\
\hline $\mathrm{P}_{\mathrm{i}}$ & $\begin{array}{l}-0.085 \\
(0.030)\end{array}$ & $\begin{array}{l}0.002 \\
(0.005)\end{array}$ & $\begin{array}{l}-0.428 \\
(0.505)\end{array}$ & $\begin{array}{l}-0.083^{* *} \\
(0.030)\end{array}$ & $\begin{array}{l}0.002 \\
(0.005)\end{array}$ & $\begin{array}{l}0.001) \\
(0.094)\end{array}$ & $\begin{array}{l}-0.083 * * \\
(0.030)\end{array}$ & $\begin{array}{l}0.002 \\
(0.005)\end{array}$ & $\begin{array}{l}0.001 \\
(0.094)\end{array}$ \\
\hline Constant & $\begin{array}{l}0.047 \\
(0.054)\end{array}$ & $\begin{array}{l}-0.293 * * * \\
(0.011)\end{array}$ & $\begin{array}{l}-0.522 * * * \\
(0.169)\end{array}$ & $\begin{array}{l}-0.045 \\
(0.055)\end{array}$ & $\begin{array}{l}-0.293 * * * \\
(0.011)\end{array}$ & $\begin{array}{l}-0.522 * * * \\
(0.169)\end{array}$ & $\begin{array}{l}-0.045 \\
(0.055)\end{array}$ & $\begin{array}{l}-0.293 * * * \\
(0.011)\end{array}$ & $\begin{array}{l}-0.522 * * * \\
(0.169)\end{array}$ \\
\hline Observations & 2531 & 2531 & 2531 & 2531 & 2531 & 2531 & 2531 & 2531 & 2531 \\
\hline FTA-goods & 1237 & 1237 & 1237 & 1226 & 1226 & 1226 & 1226 & 1226 & 1226 \\
\hline Adj. $R^{2}$ & 0.372 & 0.513 & 0.060 & 0.238 & 0.490 & 0.060 & 0.238 & 0.513 & 0.060 \\
\hline Shea's partial $\mathrm{R}^{2}$ & 0.231 & 0.489 & 0.056 & 0.233 & 0.513 & 0.056 & 0.233 & 0.490 & 0.056 \\
\hline F-test excl. P-val. & 0.000 & 0.000 & 0.045 & 0.000 & 0.000 & 0.045 & 0.000 & 0.000 & 0.001 \\
\hline
\end{tabular}

Notes: All regressions are based on heteroskedasticity robust standard errors and clustering at the ISIC 3-digti industry level. *, **,*** illustrate the $10 \%, 5 \%, 1 \%$ significance levels, respectively. The displayed F-test at the bottom of table 12 reports the probability value for the rejection of the hypothesis that all excluded instruments are jointly insignificant. The probability values for standard partial $R^{2}$ and Shea's $R^{2}$ are reasonably close pointing to the sufficient relevance for the instruments to explain the endogenous regressors. All F-statistics for the preference indicator variable and the reciprocity proxy variable exceed 10, while the F-statistics of political economy variable reports values that vary around 2.3. 
Annex Table 5: Japanese MFN Tariff Cuts and GSP Preferences: Excluding individual covariates

\begin{tabular}{|c|c|c|c|c|c|c|c|c|c|c|}
\hline & \multicolumn{5}{|c|}{ OLS } & \multicolumn{5}{|c|}{ IV-GMM } \\
\hline & (1) & (2) & (3) & (4) & (5) & (6) & (7) & (8) & (9) & (10) \\
\hline & $\begin{array}{c}\text { GSP } \\
\text { Preferences } \\
\text { (Baseline) }\end{array}$ & $\begin{array}{c}\text { GSP } \\
\text { Preferences }\end{array}$ & $\begin{array}{c}\text { GSP } \\
\text { Preferences }\end{array}$ & $\begin{array}{c}\text { GSP } \\
\text { Preferences }\end{array}$ & $\begin{array}{c}\text { GSP } \\
\text { Preferences }\end{array}$ & $\begin{array}{c}\text { GSP } \\
\text { Preferences } \\
\text { (Baseline) }\end{array}$ & $\begin{array}{c}\text { GSP } \\
\text { Preferences }\end{array}$ & $\begin{array}{c}\text { GSP } \\
\text { Preferences }\end{array}$ & $\begin{array}{c}\text { GSP } \\
\text { Preferences }\end{array}$ & $\begin{array}{c}\text { GSP } \\
\text { Preferences }\end{array}$ \\
\hline $\mathrm{I}_{\mathrm{i}}^{\mathrm{j \ddagger}}$ & $\begin{array}{l}0.018 * * * \\
(0.003)\end{array}$ & $\begin{array}{l}0.018 * * * \\
(0.003)\end{array}$ & $\begin{array}{l}0.018 * * * \\
(0.003)\end{array}$ & $\begin{array}{l}0.018 * * * \\
(0.003)\end{array}$ & $\begin{array}{l}0.014 * * * \\
(0.003)\end{array}$ & $\begin{array}{l}0.017 * * * \\
(0.002)\end{array}$ & $\begin{array}{l}0.018 * * * \\
(0.002)\end{array}$ & $\begin{array}{l}0.010^{* * * *} \\
(0.003)\end{array}$ & $\begin{array}{l}0.009 * * * \\
(0.003)\end{array}$ & $\begin{array}{l}0.007 * * \\
(0.003)\end{array}$ \\
\hline $\mathrm{R}_{\mathrm{i}}^{*}$ & $\begin{array}{l}0.002 \\
(0.006)\end{array}$ & & & & & $\begin{array}{l}-0.010^{*} \\
(0.006)\end{array}$ & & & & \\
\hline$\Delta \mathbf{x}$ & $\begin{array}{l}0.003 \\
(0.002)\end{array}$ & $\begin{array}{l}0.003 \\
(0.002)\end{array}$ & & & & $\begin{array}{l}0.011 * \\
(0.006)\end{array}$ & $\begin{array}{l}0.009 \\
(0.006)\end{array}$ & & & \\
\hline $\mathrm{P}_{\mathrm{i}}$ & $\begin{array}{l}-0.001 \\
(0.002)\end{array}$ & $\begin{array}{l}-0.001 \\
(0.002)\end{array}$ & $\begin{array}{l}-0.002 \\
(0.002)\end{array}$ & & & $\begin{array}{l}-0.001 \\
(0.001)\end{array}$ & $\begin{array}{l}-0.001 \\
(0.001)\end{array}$ & $\begin{array}{l}-0.001 * \\
(0.001)\end{array}$ & & \\
\hline$t_{i, t-1}$ & $\begin{array}{l}-0.376^{* * *} \\
(0.017)\end{array}$ & $\begin{array}{l}-0.376^{* * * *} \\
(0.017)\end{array}$ & $\begin{array}{l}-0.370 * * * \\
(0.017)\end{array}$ & $\begin{array}{l}-0.370^{* * * *} \\
(0.017)\end{array}$ & & $\begin{array}{l}-0.334 * * * \\
(0.074)\end{array}$ & $\begin{array}{l}-0.350 * * * \\
(0.076)\end{array}$ & $\begin{array}{l}-0.308^{* * *} \\
(0.093)\end{array}$ & $\begin{array}{l}-0.290 * * * \\
(0.093)\end{array}$ & \\
\hline Constant & $\begin{array}{l}-0.021 * * * \\
(0.005)\end{array}$ & $\begin{array}{l}-0.022 * * * \\
(0.004)\end{array}$ & $\begin{array}{l}-0.024 * * * \\
(0.004)\end{array}$ & $\begin{array}{l}-0.025^{* * *} \\
(0.003)\end{array}$ & $\begin{array}{l}-0.045 * * * \\
(0.002)\end{array}$ & $\begin{array}{l}-0.022 * * * \\
(0.006)\end{array}$ & $\begin{array}{l}-0.018 * * * \\
(0.004)\end{array}$ & $\begin{array}{l}-0.025^{* * *} \\
(0.005)\end{array}$ & $\begin{array}{l}-0.026^{* * *} \\
(0.005)\end{array}$ & $\begin{array}{l}-0.042 * * * \\
(0.001)\end{array}$ \\
\hline Observations & 2532 & 2532 & 2532 & 2532 & 2532 & 2532 & 2532 & 2532 & 2532 & 2532 \\
\hline $\begin{array}{l}\text { Number of FTA } \\
\text { goods }\end{array}$ & 1226 & 1226 & 1226 & 1226 & 1226 & 1226 & 1226 & 1226 & 1226 & 1226 \\
\hline Hansen's J (p-val.) & - & - & - & - & - & 0.673 & 0.6600 & 0.941 & 0.947 & 0.485 \\
\hline C-stat (p-val.) & - & - & - & - & - & 0.655 & 0.6098 & 0.952 & 0.958 & 0.478 \\
\hline Endogeneity (p-val.) & - & - & - & - & - & 0.442 & 0.574 & 0.033 & 0.021 & 0.166 \\
\hline Heterosked. (p-val.) & 0.000 & 0.000 & 0.000 & 0.000 & 0.000 & 0.000 & 0.000 & 0.000 & 0.000 & 0.000 \\
\hline
\end{tabular}


Annex Table 6: Tobit model: Uruguay Bound Tariffs Concessions and GSP Trade Preferences

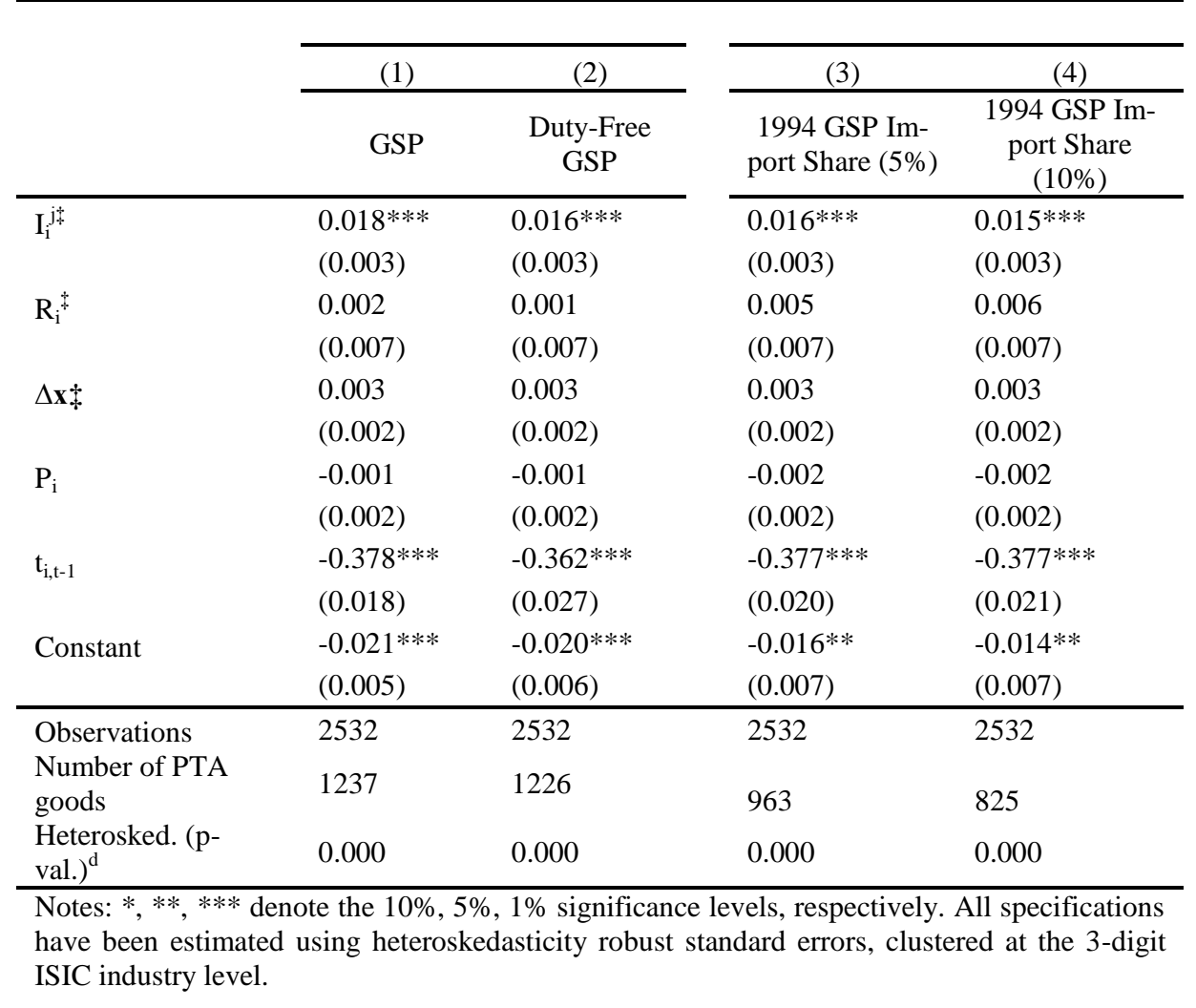

Annex Figure 1: Japan's Applied Average MFN and GSP Preferential Tariffs: 1988-2010

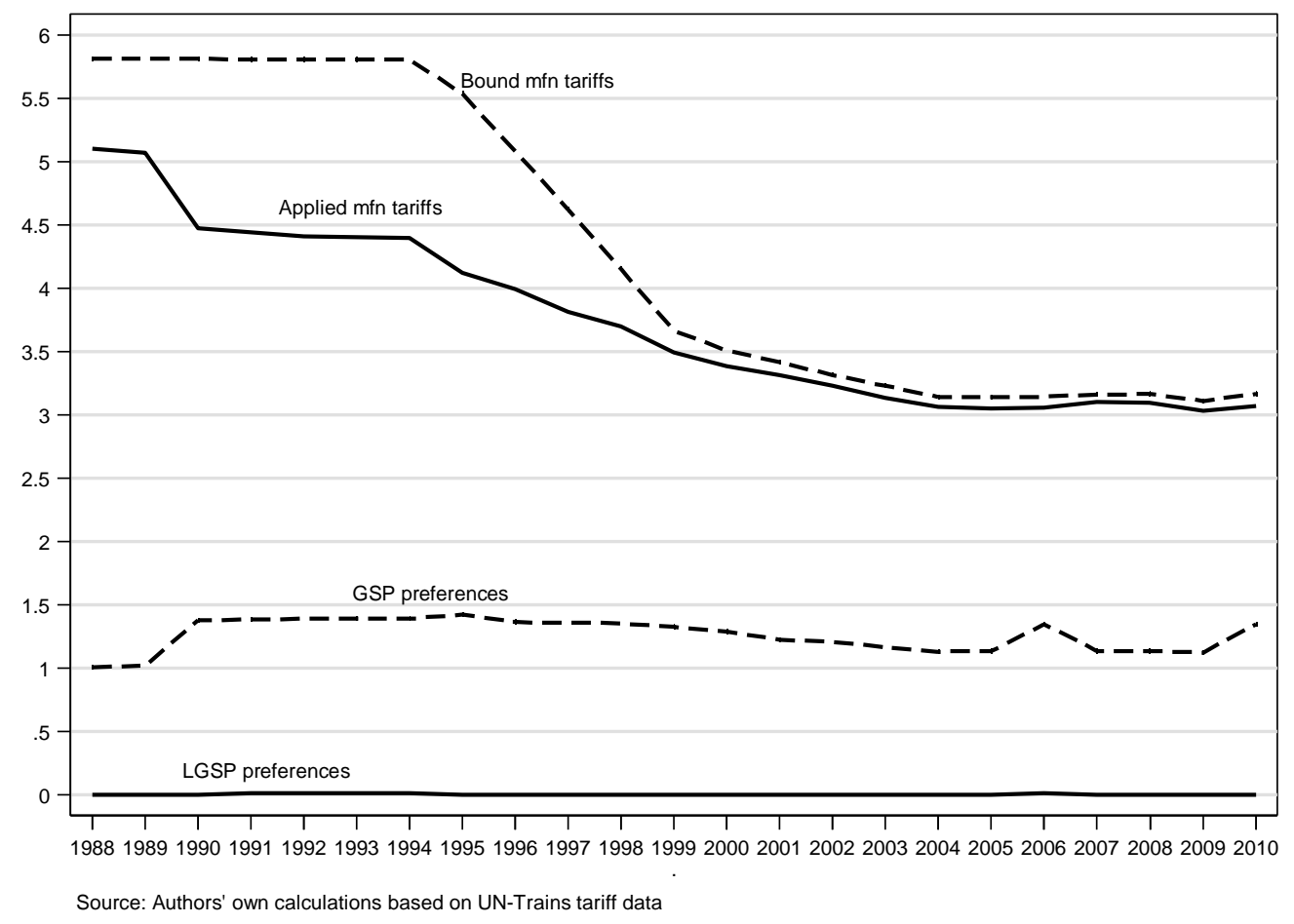

